\title{
花粉，瓦斯代謝二就 テ
}

奧 貫 一 男

KaZuo Okunuki: Über den Gaswechsel des Pollens.

Reciev"d, July 13, 1932.

緒 言

花粉及ビ花粉管二關スル研究ハ古クョリ多々アリ枚擧スルニ遑ナシト雖大別シテ 細胞學的研究卜生理學的研究トナスコトガ出來ル。其ノ內生理學的研究=關シテノ ミ略述スレバ、授粉二關係シタル研究トシテ花粉/發芽及ビ花粉管ノ伸長二及ボス 種队ナル物質或八條件ノ影響卜生物化學的=花粉及ビ花粉管つ生成スル酵素=關シ テノ研究トヨ擧ゲルコトガ出來ル。Y. ToKUGAWA, 1) R. A. BRINK, ${ }^{2)}$ K. Gотон ${ }^{3)}$

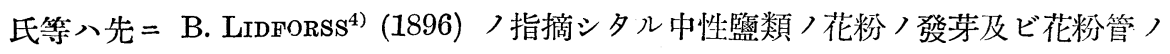
伸長 =及ボス阻害作用ヨ充分 $=$ 研究シテ、コレ等鹽類ノ阻害作用ノ大ナルモノ八花

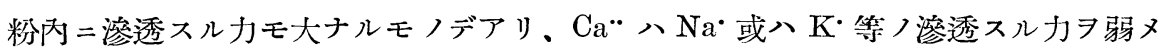
ルカ或八妨害スルモノデアルト結論シテキル。更二又蔗糖ノ適當ナル濃度ガ花粉ノ 發芽及ビ花粉管ノ伸長二對シテ著シク促進的二作用スルノ八蔴糖ガ榮養物トシテ價 值アルニ由ルモノデハナク最適ナル淩透壓ヨ與ヘル雼メデアルトイフ。叉、C.PICADo, ${ }^{5)}$ D. F. Jones, ${ }^{\text {) }}$ E. Katz, ${ }^{7)}$ S. YaSUda. ${ }^{8)}$ H. Schoch-Bodmer, ${ }^{9)}$ P. Bran-

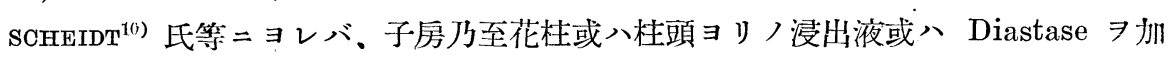
ヘルト花粉管ノ伸長ガ 著シク促進サレルコト並ビ二蛋白質及ビソノ分解物質或八 Pepsin 等ニョリ阻害的二作用サレルコトガ知ラレテ+ル。J. B. PATON ${ }^{11)}$ 八種々 ナル植物ニツキ花粉及ビ花粉管中二生成セラレタル酵素二關シテ實驗ヨナシ細胞膜 ヨ締シテキル Mittellamella 郎チ Pektinstoff ヨ破瀤スル Pektinase ノ存在スル コトヨ證明シテ STRASBURGER 等ノ細胞學者ガ認メタル結果節チ花粉管ガ花柱組織 ヨ通過スル場合二八花粉管ハ細胞中ヨ通拔ケルノデハナク細胞卜細胞卜ノ間ヨ通ル

1) Y. Tokugawa: Journ. Coll. Sci. Tokyo, 35, 1914, 1-35.

2) R. A. Brink: Bot. Gaz. 78, 1924, 361; Am. J. of Bot. 12, 1925, 149 ; J. of gen. Physiol, 6, 1924, 677.

3) K. Gотон: Memoirs of the Fac. Sci. et Agri. Taihoku, 3, 1931, 62.

4) B. Lidforss: Jahrb. wiss. Bot., 23, 1896, 1.

5) C. Picado: Compt. rend. séa. soc. biol., 87, 1922, 924.

6) D. F. Jones: Biol. bull. marine biol. lab., 43, 1922, 167.

7) E. KAтZ: Flora, 20, 1926, 243.

8) S. YASuda: Bot. Mag. (Tokyo), 44, 1930, 392;

9) H. Schoch-Bodmer: Ber. schw. bot. Ges., 39, 1930, 15.

10) P. Branscheidt: Planta, 11, 1930, 368.

11) J. B. Paton: Am. J. Bot. 8, 1921, 471. 
トイフ結果习肯定シ、更二花粉管ノ伸長速度ガ $\mathrm{Ca}$ イオン =ョリ促進サレルノハ Mittellamella ガ $\mathrm{Ca}$ フ含有シテキルコトトヨク符合シ興味アル問題 7 提供シテ市 ルト論ジテ市ル。然ル＼cjkstart花粉ノ代謝生理ノ方面二關スル研究ハ未ダ見當ラザル $=ヨ$ リ、自分八椿 (Camellia japonica, L.) 及ビ山百合 Lilium auratum, LINDL) 等) 花粉ニツキ實驗セル所ヨ論ジ此處ニ報告セントスルモノデアル。

方法

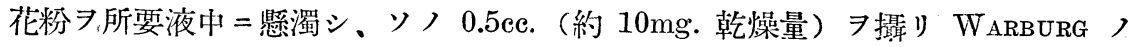

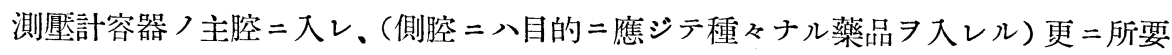
試藥溶液习加へテ 1.0ec. トナシ椿ノ場合二ハ $20^{\circ} \mathrm{C}$, 百合ノ場合ニハ $25^{\circ} \mathrm{C}=$ 於

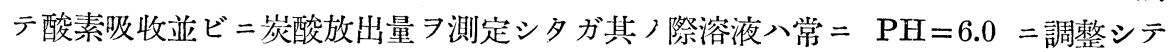
實驗二用年夕。花粉管/伸長八接眼ミクロメーターニヨリ測定シ、發芽率ヨ考虑シ

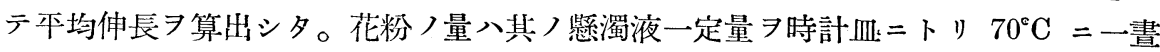
夜乾燥シタル後 $\mathrm{CaCl}_{2}$ エキシカトール中ニ於テ放冷シタル後科量シ決定シタ。

實 驗 記 述

1. 䜍種ノ花粉ニ於ヶル酸素吸收量卜炭酸放出量。

前述ノ如クシテ作リタル諸種ノ花粉眯濁液中ニ於イテ測定シタル瓦斯代謝ノ結果 八次ノ如クデアル。（第一表參照）

花粉 =於ケル酸素吸收量並ビニ炭 酸放出量八比較的小デアル。

2. 䒺ニ於ヶル花粉ノ瓦斯代謝 椿或八百合ノ花粉ノミア葯ヨリ攝 リ、コレヨ正シク $20 \mathrm{mg}$. 宛科量シ テ.WARBURG 測壓計容器ノ主腔= 入レ、側腔二適當ナル濃度ノ糖液或 八蒸溜水 ミノ場合ノ瓦斯代謝 $7 、$ 次二側腔內 糖液或八蒸溜水 $\ni$ 主腔中 $=$ 流入七 第 一 表 シメテ糖液內ニ於ケル瓦斯代謝习測定シタ。

第一、第二表及ビ第一圖/示スガ如ク椿二於テモ鐵砲百合二於テモ同樣二花粉， ミデ八瓦斯代謝ガ極メテ僅少デアルガ糖液又八蒸溜水》加へルト忽チ多量ノ瓦斯代

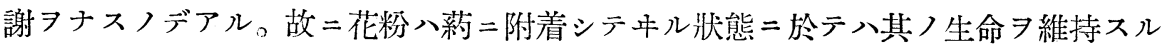
二必要ナル最少限度)瓦斯代謝ヨナシティルノデアルガ一度花粉ガ 適當ナル條件 (濕度) =置カレルト直チニ發芽センガ爲メ =生活機能 7 覺醒セシメテ多量 瓦斯代

1) $Q_{\mathrm{O}_{2}}$ 八、花粉輇燥量 $1 \mathrm{mg}$. ガ 1 時間二吸收スル酸素量 $(\mathrm{cmm})$ ヨ表ハス。

2) $Q_{\mathrm{CO}}^{\mathrm{N}_{2}}$ 八窒素中 =於テ花粉乾燥量 $1 \mathrm{mg}$ ガ 1 時間=放出スル宸酸量 $(\mathrm{cmm})$ ヨ表ハス。 
第 一 圖

つばきノ花粉ノ瓦斯代謝

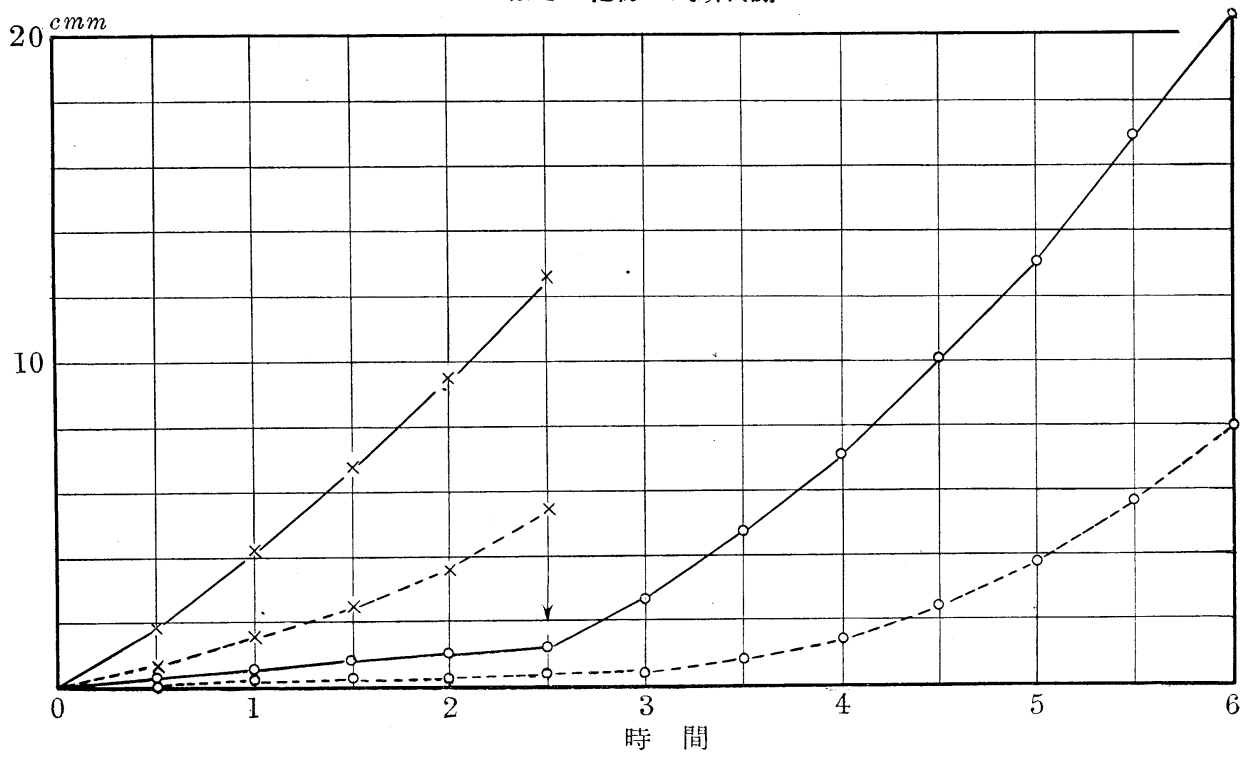

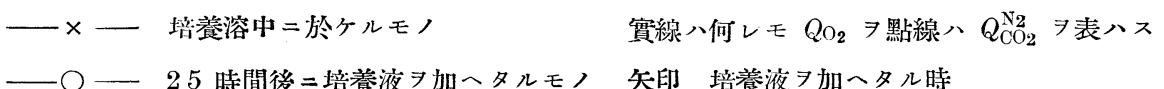
第 一 表

\begin{tabular}{|c|c|c|c|c|}
\hline \multirow{3}{*}{$\begin{array}{l}\text { 時 間 } \\
\text { (分) }\end{array}$} & \multicolumn{4}{|c|}{ つばきノ花汾 $1 \mathrm{mg}$ (乾懆量) =對スル } \\
\hline & \multicolumn{2}{|c|}{ 酸素吸收 量 } & \multicolumn{2}{|c|}{ 炭酸放出量 } \\
\hline & $\begin{array}{c}\text { 培養液山二於 } \\
\text { ケルモノ }\end{array}$ & $\mid \begin{array}{c}150 \text { 分後二培養 } \\
\text { 液 }\end{array}$ & $\begin{array}{c}\text { 培臹液中=於 } \\
\text { ケルモノ }\end{array}$ & 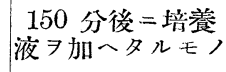 \\
\hline 30 & $\begin{array}{l}\mathrm{cmm} \\
1.76\end{array}$ & $\begin{array}{l}\mathrm{cmm} \\
0.21\end{array}$ & $\begin{array}{l}\mathrm{cmm} \\
0.69\end{array}$ & $\begin{array}{l}\mathrm{cmm} \\
0.11\end{array}$ \\
\hline 60 & 4.24 & 0.48 & 1.51 & 0.23 \\
\hline 90 & 6.69 & 0.74 & 2.38 & 0.23 \\
\hline 120 & 9.53 & 0.96 & 3.63 & 0.23 \\
\hline 150 & 12.74 & 1.12 & 5.67 & 0.29 \\
\hline 180 & & 2.75 & & 0.40 \\
\hline 210 & & 4.82 & & 0.74 \\
\hline 240 & & 7.26 & & 1.37 \\
\hline 270 & & 10.13 & & 2.40 \\
\hline 300 & & 13.16 & & 3.77 \\
\hline 330 & & 16.93 & & 5.71 \\
\hline 360 & & 20.65 & & 7.93 \\
\hline
\end{tabular}


第 $\quad$ 表

\begin{tabular}{|c|c|c|c|c|}
\hline \multirow{3}{*}{$\begin{array}{l}\text { 時 間 } \\
\text { (分) }\end{array}$} & \multicolumn{4}{|c|}{ てつぱらゆりノ花粉 $1 \mathrm{mg}$. (豍燥量) =對スル } \\
\hline & \multicolumn{2}{|c|}{ 酸素吸收量 } & \multicolumn{2}{|c|}{ 宸酸放出量 } \\
\hline & $\begin{array}{l}\text { 蒸溜水中=於 } \\
\text { ケルモ }\end{array}$ & 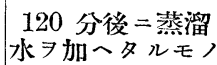 & $\begin{array}{l}\text { 蒸溜水中=於 } \\
\text { 沗ルモ, }\end{array}$ & 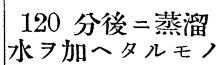 \\
\hline 30 & $\begin{array}{l}\operatorname{cim} \\
5.17\end{array}$ & $\begin{array}{l}\operatorname{comm}_{0.52} \\
0.52\end{array}$ & $\begin{array}{l}\operatorname{comm} \\
3.83\end{array}$ & $\begin{array}{l}\mathrm{cmm} \\
0.03\end{array}$ \\
\hline 60 & 8.47 & 0.93 & 6.54 & 0.06 \\
\hline 90 & 10.40 & 1.24 & 8.19 & 0.10 \\
\hline 120 & 11.99 & 1.75 & 9.17 & 0.12 \\
\hline 150 & & 3.73 & & 0.90 \\
\hline 180 & & 8.50 & & 4.30 \\
\hline 210 & & 11.82 & & 6.33 \\
\hline 240 & & 13.69 & & 7.91 \\
\hline 270 & & 15.45 & & 9.27 \\
\hline 300 & & 16.38 & & 10.43 \\
\hline
\end{tabular}

謝ヨナスノデアルト考へラレル。從ツテ葯ガ破レテ後雨ナド二逢ハバ忽チ花粉八發

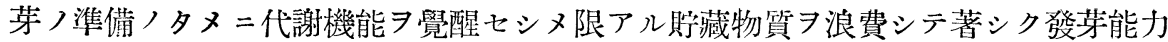
ヨ減少セシメルカ或八一度代謝機能习覺醒七ル花粉八外況/變化二對シテ抵抗力 減少スルト考へルテラ濕度ノ變化ニヨリ花粉ノ發芽力ガ甚ダシク減殺サレルトイフ 事實习說明シ得ルト考へラレルノデアル。

\begin{tabular}{|c|c|c|c|c|}
\hline \multirow{3}{*}{$\begin{array}{l}\text { 時 間 } \\
\text { (分) }\end{array}$} & \multicolumn{4}{|c|}{ つぱきノ花㸮 $1 \mathrm{mg}$. (乾懆量) =對スル } \\
\hline & \multicolumn{2}{|c|}{ 酸素吸收量 } & \multicolumn{2}{|c|}{ 崖酸放出量 } \\
\hline & $\begin{array}{c}\text { 蔗糖液中二於 } \\
\text { ケルモノ }\end{array}$ & $\begin{array}{c}\text { 蒸溜水中=於 } \\
\text { ケルモノ }\end{array}$ & $\begin{array}{c}\text { 䒰糖液中二於 } \\
\text { ケルモノ }\end{array}$ & $\begin{array}{l}\text { 蒸溜水中二於 } \\
\text { ケルモノ }\end{array}$ \\
\hline 15 & $\begin{array}{l}\mathrm{cmm} \\
0.91\end{array}$ & $\begin{array}{l}\operatorname{comm}_{0.5} \\
0.59\end{array}$ & $\begin{array}{r}\operatorname{cmm} \\
0\end{array}$ & $\begin{array}{r}\mathrm{cmm} \\
0\end{array}$ \\
\hline 30 & 2.44 & 1.88 & 0 & 0 \\
\hline 45 & 4.18 & 3.24 & 0.19 & 0.12 \\
\hline 60 & 6.13 & 4.70 & 0.73 & 0.46 \\
\hline 75 & 8.08 & 6.23 & 1.23 & 0.65 \\
\hline 90 & 10.21 & 7.77 & 1.92 & 1.00 \\
\hline 105 & 12.47 & 9.40 & 2.73 & 1.35 \\
\hline 120 & 14.80 & 10.94 & 3.54 & 1.69 \\
\hline$Q_{\mathrm{O}_{2}}$ & 7.40 & 5.47 & & \\
\hline$Q_{\mathrm{CO}_{2}}^{\mathrm{N}_{2}}$ & & & 1.77 & 0.84 \\
\hline
\end{tabular}


第四表

\begin{tabular}{|c|c|c|c|c|}
\hline \multirow{3}{*}{$\begin{array}{c}\text { 時 間 } \\
\text { (分) }\end{array}$} & \multicolumn{4}{|c|}{ やまゆりノ花粉 $1 \mathrm{mg}$ (乾燥量) =對スル } \\
\hline & \multicolumn{2}{|c|}{ 酸素吸收量 } & \multicolumn{2}{|c|}{ 宸酸放出量 } \\
\hline & $\begin{array}{l}\text { 葡萄糖液中= } \\
\text { 於ケルモノ }\end{array}$ & $\begin{array}{c}\text { 蒸溜水中=於 } \\
\text { ケルモノ }\end{array}$ & $\begin{array}{l}\text { 葡菊糖液中二 } \\
\text { 於ケルモ， }\end{array}$ & $\begin{array}{c}\text { 蒸溜水中二於 } \\
\text { ケルモノ }\end{array}$ \\
\hline $\begin{array}{r}15 \\
30 \\
45 \\
60 \\
90 \\
120 \\
150 \\
180\end{array}$ & $\begin{array}{r}\text { cmm } \\
2.91 \\
6.40 \\
8.85 \\
10.77 \\
13.17 \\
14.99 \\
16.60 \\
17.96\end{array}$ & $\begin{array}{r}\mathrm{cmm} \\
3.14 \\
6.54 \\
8.90 \\
10.99 \\
13.13 \\
14.95 \\
16.72 \\
18.23\end{array}$ & $\begin{array}{r}\mathrm{cmm} \\
261 \\
5.54 \\
7.86 \\
9.59 \\
11.03 \\
12.10 \\
12.97 \\
13.61\end{array}$ & $\begin{array}{r}\text { emnl } \\
2.78 \\
5.68 \\
8.07 \\
9.94 \\
11.33 \\
12.33 \\
13.06 \\
13.69\end{array}$ \\
\hline$Q_{\mathrm{O}_{2}}$ & 5.99 & 6.07 & & \\
\hline$Q_{\mathrm{CO}_{2}}^{\mathrm{N}_{2}}$ & & & 4.54 & 4.56 \\
\hline
\end{tabular}

3. 花粉ノ瓦斯代謝 $=$ 及ボス糖ノ影響

、花粉管ノ伸長二際シテ茩糖〉存在 八適當ナル渗透壓ヨ與ヘル䉆メ二必 要ナノデアツテ榮養トシテ役立ツコ トハ極メテ少イト考へラレテキル。 實際多クノ種類つ花粉八蒸溜水 ${ }^{1)}$ 中 デモ發芽シ、可ナリ花粉管〉伸長ス ルコト及ピ花粉管〉伸長八蔴糖液中 デモ、蒸溜水中デモ殆ドソノ伸長度 二差異ナキコトモ知ラレテキル。因 ツテ瓦斯代謝ノ見地ヨリミテ上述ノ 考へガ果シテ正シイカ厑カ椿及ビ山 百合)花粉二就テ次表 =示スガ如キ

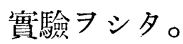

第三表及ビ第二圖並ビ二第四表參 照。

第 二 圖

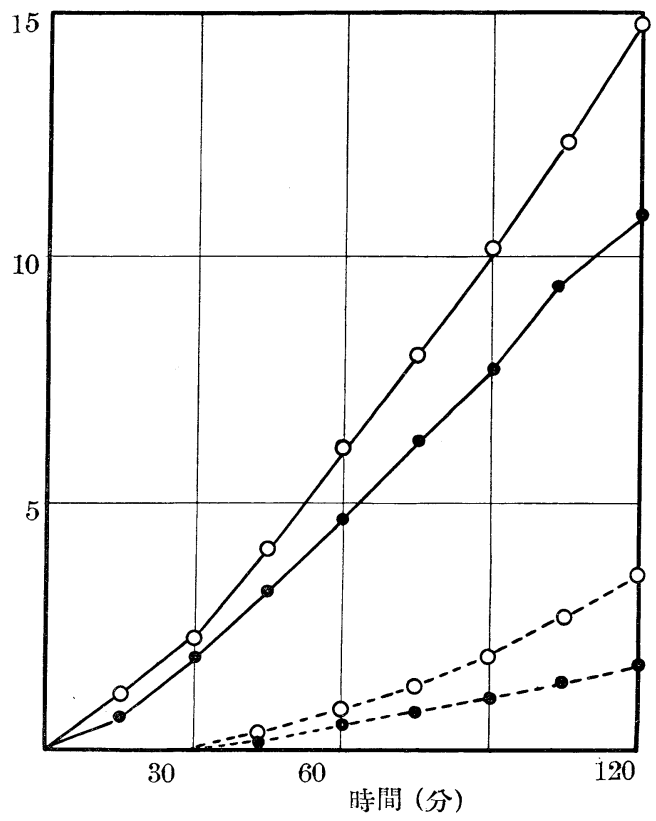

成程多クノ研究者ガ實驗セ儿如ク 花粉管ノ伸長二八蔴糖〉存在ノ有無 ニョル差異八殆ドミラレナイガ椿ノ

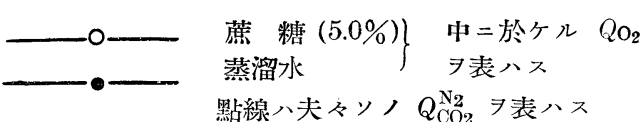

點線ハ夫々ソノ $Q_{\mathrm{CO} 2}^{\mathrm{N}_{2}}$ ヨ表ハス

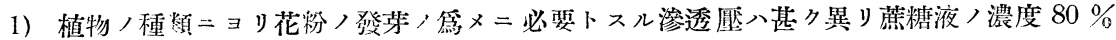

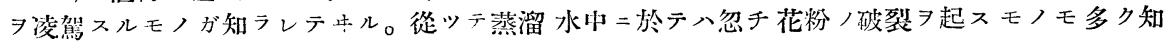
ラレテキル。 
花粉ニ於ケル酸素吸收及ビ炭酸放出量八莣糖)存在ニョリ明二增加セシメラレル, デアル。然ル二山百合ノ場合ニハ少クトモ三時間ノ實驗時間中 =於テハ糖ノ存在 $=$ ヨル瓦斯代謝ノ變化ハ全ク認メラレナカツタノデアル。從ツテ山百合ノ場合ニアツ テハ糖ガ花粉管ノ伸長二際シテ榮養トナラズトイフ結論入正シイガ椿ノ場合ニ於テ ハ少シク穻當习缺クノデアル。コレヨ要スル二花粉ノ弡芽及ビ花粉管ノ伸長ノ初メ 八花粉內ノ貯藏物質ノミヨ營養物トシテ用キテ不足ナラザルモ花粉管〉甚ダシク伸 長セル後二於テハ糖モ營養トシテ用キラレルモノト考へラレル，事實柱頭二到達セ

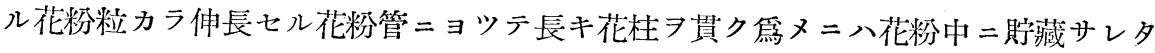
ル物筫ノミデ八到底不可能卜考へラレル場合ガ多々アルノデアルカラ、上述ノ考へ 八正シイト信ゼラレル。

\section{4. 花粉ノ瓦斯代謝二及ボス種くナル鹽類つ影響}

花粉ノ發芽及ビ花粉管つ伸長二對シテ種及つ鹽類ガ $\mathrm{M} / 100-\mathrm{M} / 1000$ 程度二於テ 極メテ强ク阻害的二作用スルコトハ既＝B. LIDFORSS ${ }^{2)}$ ノ指摘シテ立ル所デアル。

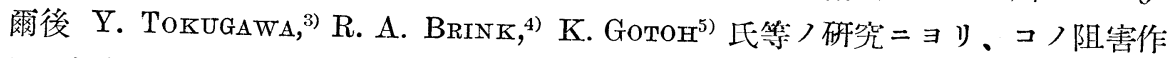
用八植物ノ種類ニョリソノ影響つ程度=美異アルコト及ビソノ阻害作用八鹽類ノイ オンガ花汾內二滲透スル力ノ大ナルモ゙程、ソノ阻害作用モ大デアルコトガ明二サ レティルノデアル。從ツテ諸種ノイオンノ阻害作用ノ程度ニョリ順列ヨ作レバ所謂 HOFMEISTER イオン系列、或ハLyotrope Reihe トナルトイフ。自分ハコノ阻害作 用 ヨ受ケタル花粉ノ瓦斯代謝ガ如何二影響习受ケルカニ就テ、陰イオンノ場合二入 カリウム鹽ヨ、陽イオンノ場合ニハクロール鹽ヨ用中テ實驗シタノデアル。其ノ際

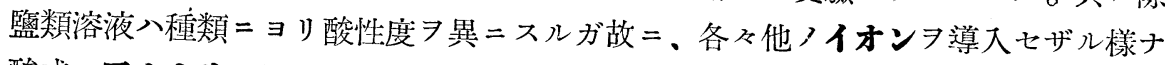
酸或ハアルカリ

I. 椿)花粉

\section{1. 陰イオン}

i) $\mathrm{K}_{3} \mathrm{PO}_{4}$

種ふナル濃度二於テ實驗セル二酸素吸收量ハ比較的ニ著シキ阻害作用ヨ受ヶザル モ $(\mathrm{M} / 100$ デ $56 \%)$ 無酸素狀態ノ炭酸放出量八全ク阻止サレ、M/300 ヨ加へタル 場合二ノミ僅カー $24 \%$ 見ラレタノデアル。發芽八窒素 度二於テハ相當ニヨク行ハレルガ、THUNBERG 管內ニ於テ眞空ニナス時八全クミラ レナクナルノデアル。發芽率八空氣酸素ノ存在スル場合二八濃度 $\mathrm{M} / 200$ 二於テ 23.8\% フ示ス =對シ窒素中二於テハ $32.8 \%$ デアル。(第五表及實驗記錄第一参照)

ii) $\mathrm{K}_{2} \mathrm{SO}_{4}$

酸素吸收量八濃度 $\mathrm{M} / 100$ =於テ著シク阻害 $(66 \%)$ サレルガ炭酸放出量八更二强

2) B. Linforss : loc. cit.

3) Y. Tokugawa: loc. cit.

4) R. A. Brink: loc. cit.

5) K. Gотон: loc. cit. 
第五表

\begin{tabular}{|c|c|c|c|c|c|c|c|}
\hline & & \multirow{2}{*}{$\underbrace{}_{\text {監 }}$} & \multicolumn{5}{|c|}{ 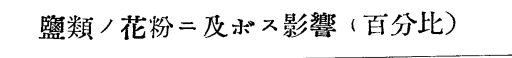 } \\
\hline & & & 0 & $\mathrm{M} / 50$ & $\mathbf{M} / 100$ & $\mathbf{M} / 200$ & $\mathrm{M} / 300$ \\
\hline \multirow{4}{*}{ 空 } & \multirow{2}{*}{$\begin{array}{c}\text { 酸 素 } \\
\text { 吸收 量 } \\
\left(Q_{\mathrm{O}_{2}}\right)\end{array}$} & $\begin{array}{c}\mathrm{KCl} \\
\mathrm{K}_{3} \mathrm{PO}_{4} \\
\mathrm{CH}_{3} \mathrm{COOK} \\
\mathrm{K}_{2} \mathrm{SO}_{4} \\
\mathrm{KNO}_{3}\end{array}$ & $\begin{array}{c}100 \\
1 " \\
" 1 \\
" 1 \\
" 1\end{array}$ & $\begin{array}{l}62 \\
46 \\
29 \\
24 \\
\end{array}$ & $\begin{array}{l}79 \\
44 \\
78 \\
34 \\
28 \\
\end{array}$ & 66 & $\begin{array}{l}97 \\
80 \\
91 \\
74 \\
60\end{array}$ \\
\hline & & $\begin{array}{c}\mathrm{CaCl}_{2} \\
\mathrm{MgCl}_{2} \\
\mathrm{NaCl} \\
\mathrm{KCl} \\
\mathrm{LiCl}\end{array}$ & $\begin{array}{c}100 \\
\text { " } \\
\text { " } \\
\text { " }\end{array}$ & $\begin{array}{l}78 \\
58 \\
56 \\
55 \\
37\end{array}$ & $\begin{array}{l}85 \\
61 \\
72 \\
65 \\
39 \\
\end{array}$ & & $\begin{array}{l}96 \\
82 \\
91 \\
84 \\
53 \\
\end{array}$ \\
\hline & \multirow{2}{*}{$\begin{array}{l}\text { 花 粉 管 } \\
\text { 伸 長 }\end{array}$} & $\begin{array}{c}\mathrm{KCl} \\
\mathrm{K}_{3} \mathrm{PO}_{4} \\
\mathrm{CH}_{3} \mathrm{COOK} \\
\mathrm{K}_{2} \mathrm{SO}_{4} \\
\mathrm{KNO}_{3} \\
\end{array}$ & $\begin{array}{c}100 \\
" 1 \\
" \\
" 1 \\
" 1\end{array}$ & $\begin{array}{l}0 \\
0 \\
0\end{array}$ & $\begin{array}{r}24 \\
1 \\
3 \\
0 \\
0\end{array}$ & 4 & $\begin{array}{l}46 \\
17 \\
45 \\
14 \\
15 \\
\end{array}$ \\
\hline & & $\begin{array}{c}\mathrm{CaCl}_{2} \\
\mathrm{MgCl}_{2} \\
\mathrm{KCl} \\
\mathrm{NaCl} \\
\mathrm{LiCl}\end{array}$ & $\begin{array}{l}100 \\
\text { " } \\
\text { " } \\
\text { " }\end{array}$ & $\begin{array}{l}6 \\
6 \\
1 \\
1 \\
0 \\
\end{array}$ & $\begin{array}{r}48 \\
21 \\
9 \\
8 \\
0\end{array}$ & & $\begin{array}{r}98 \\
60 \\
56 \\
55 \\
0 \\
\end{array}$ \\
\hline \multirow[t]{4}{*}{ 堂 } & \multirow{2}{*}{$\begin{array}{l}\text { 崖 酸 } \\
\text { 放出量 } \\
\left(Q_{\mathrm{CO}_{2}}^{\mathrm{N}_{2}}\right)\end{array}$} & $\begin{array}{c}\mathrm{KCl} \\
\mathrm{K}_{2} \mathrm{SO}_{4} \\
\mathrm{CH}_{3} \mathrm{COOK} \\
\mathrm{KNO}_{3} \\
\mathrm{~K}_{3} \mathrm{PO}_{4}\end{array}$ & $\begin{array}{c}100 \\
\text { " } \\
\text { " } \\
\text { " } \\
\text { " }\end{array}$ & $\begin{array}{r}0 \\
0 \\
15 \\
17\end{array}$ & $\begin{array}{r}51 \\
19 \\
42 \\
27 \\
0\end{array}$ & 0 & $\begin{array}{l}75 \\
44 \\
56 \\
61 \\
24 \\
\end{array}$ \\
\hline & & $\begin{array}{c}\mathrm{NaCl} \\
\mathrm{MgCl}_{2} \\
\mathrm{LiCl}\end{array}$ & $\begin{array}{l}100 \\
" 1 \\
"\end{array}$ & $\begin{array}{r}14 \\
0 \\
0\end{array}$ & $\begin{array}{r}43 \\
31 \\
0\end{array}$ & & $\begin{array}{l}56 \\
27 \\
25 \\
\end{array}$ \\
\hline & \multirow[t]{2}{*}{$\begin{array}{l}\text { 花 粉 管 } \\
\text { 伸 長 }\end{array}$} & $\begin{array}{c}\mathrm{K}_{3} \mathrm{PO}_{4} \\
\mathrm{KCl} \\
\mathrm{K}_{2} \mathrm{SO}_{4} \\
\mathrm{KNO}_{3} \\
\mathrm{CH}_{3} \mathrm{COOK} \\
\end{array}$ & $\begin{array}{c}100 \\
\text { " } \\
\text { " } \\
\text { " } \\
\text { " }\end{array}$ & $\begin{array}{r}50 \\
5 \\
0 \\
0\end{array}$ & $\begin{array}{r}13 \\
67 \\
27 \\
9 \\
9 \\
\end{array}$ & 74 & $\begin{array}{r}100 \\
104 \\
55 \\
29 \\
19 \\
\end{array}$ \\
\hline & & $\begin{array}{l}\mathrm{MgCl}_{2} \\
\mathrm{NaCl} \\
\mathrm{LiCl}\end{array}$ & $\begin{array}{l}100 \\
" 1 \\
" 1\end{array}$ & $\begin{array}{r}10 \\
17 \\
0\end{array}$ & $\begin{array}{r}28 \\
33 \\
1\end{array}$ & & $\begin{array}{r}34 \\
49 \\
3\end{array}$ \\
\hline
\end{tabular}

$81 \%$ 阻害サレル。然シ發芽率八空氣中二於テハ濃度 $\mathrm{M} / 100$ ナル場合 $=0$ デア ルガコレニ反シ窒素中 =於テハ $29 \%$ モミラレルノデアル。(第五表及實驗記錄第 二參照)

iii) $\mathrm{KNO}_{3}$ 
酸素吸收量八濃度 $\mathrm{M} / 100$ デ $72 \%$ 炭酸放出量ハ $73 \%$ 阻害サレルニ對シテ、發 芽率八窒素中二於テノミ $25.9 \%$ ミラレ、濃度 $\mathrm{M} / 300$ ニナツテ初メテ空氣中ノモ ノハ $26.4 \%$ ノ發芽率ヨ示スニスギナイノデアル。(第五表及實驗記錄第三參照）

iv) $\mathrm{KCl}$

コノ鹽類八上記ノモノニ比シテ莘シク弱キ阻害作用ヨ示スモノナレドモ侗濃度 $\mathrm{M} / 100$ 二於テ酸素吸收量八 $21 \%$ 炭酸放出量八 $49 \%$ 习阻害サレル。然シ發芽率八 空氣中=於テ $59.9 \%$ ヨ示スガ窒素中二於テハ $20.1 \%$ ニスギナイノデアル、（第五 表實驗記錄第四參照）

$$
\text { 第三圖 }
$$

つばきノ花粉ノ瓦澌代謝二及ボス $\mathrm{CH}_{3} \mathrm{COOK}$ /影響
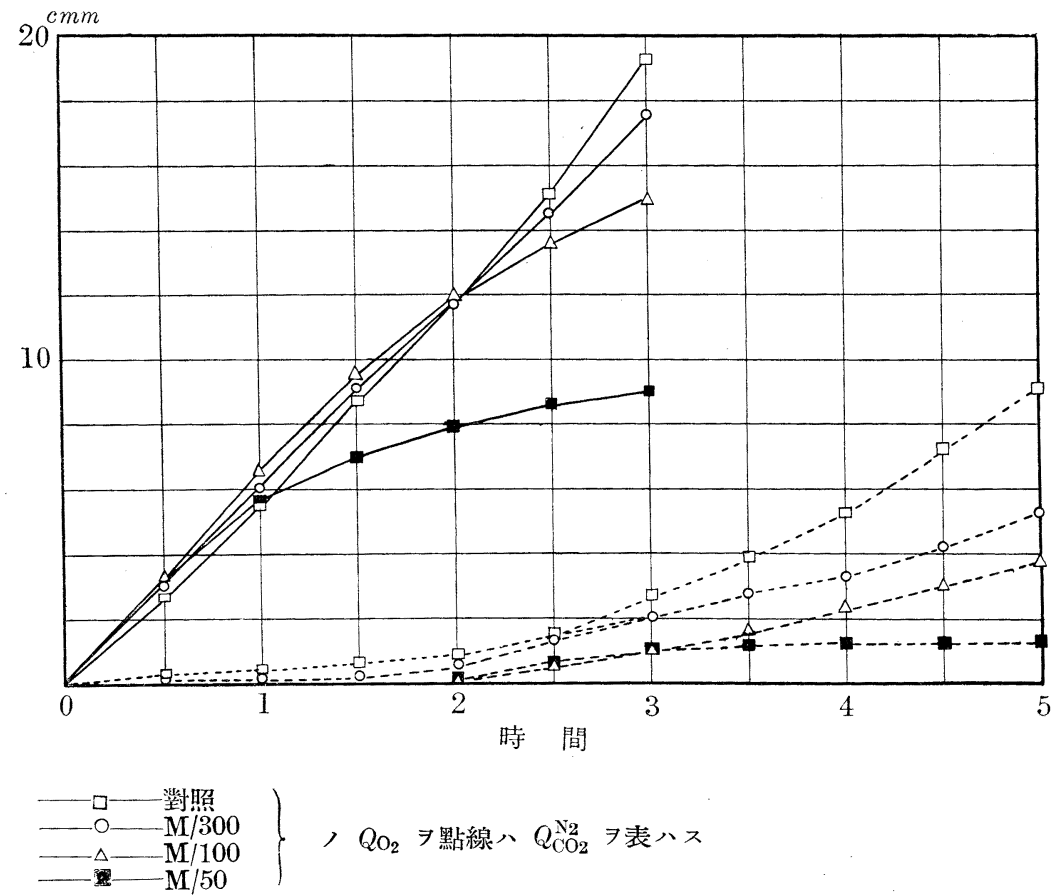

v) $\mathrm{CH}_{3} \mathrm{COOK}$

濃度 $\mathrm{M} / 100$ 二於テ酸素吸收量ハ $22 \%$ 阻害サレルガ、炭酸放出量ノ阻害ハ $58 \%$ 二達ス、然ル =發芽率八室氣中二於テ $8.1 \%$ アルニスギザレドモ空素中二於テハ 11.8\% ミラレル。（第三圖第五表及實驗記錄第五參照）

\section{2. 陽イオン*}
i) $\mathrm{NaCl}$

*) 本實驗二用+ラレタル椿ハ小石川植物園内ノ八重洖ノモノニシテ御所車卜稱バレルモノ デアル。 
比較的二阻害作用弱キモ、濃度 $M / 100=$ 於テ合酸素吸收量 $28 \%$ 炭酸放出量 $57 \%$ ガ阻害サレル。發芽率八空氣中二於テ $10.2 \%$ ヨ示ス二過ギヌガ窒素中二於テハ $36.8 \%$ モミラレタノデアル。(第五表賽驗記錄第六)

ii) $\mathrm{MgCl}_{2}$

濃度 $\mathrm{M} / 100$ 二於テ酸素吸收量入 $39 \%$ 、炭酸放出ハ $69 \%$ モ阻害サレタルニ反シ、 空氣中ニ於ケル發芽率八 $16.8 \%$ 窒素中二於ケルモノ八 $23.2 \%$ ヨ示シタノデアル。 （第五表及實驗記錄第七）

iii) $\mathrm{LiCl}$

最モ著シキ阻害作用ヨ示ス鹽ニシテ濃度 $\mathrm{M} / 100$ ナル場合酸素吸收量ハ $61 \%$ 。 濃度 $\mathrm{M} / 300$ 二於テモ向 $47 \%$ ７阻害サレル。而シテ炭酸放出量八濃度 $\mathrm{M} / 100=$ テハ全ク阻止サレ、 $\mathrm{M} / 300$ 二至リテ初メテ $25 \%$ ダケ現レルノデアル。然ル二發芽 率八濃度 $\mathrm{M} / 100$ ナル場合二窒素中二於テノミ僅カ $4.7 \%$ ミラレ濃度 $\mathrm{M} / 300$ 二於テ $9.3 \%$ トナル $=$ 反シ空氣中 =於テハ濃度 $\mathrm{M} / 300$ 二到リ僅カ $=4.7 \%$ 發芽七シメ ルニスギナイノデアル。（第五表及實驗記錄第八）

iv) $\mathrm{CaCl}_{2}$

最モ阻害作用少キモノデアル、槛物ノ種類ニョツテハ花粉管伸長忍促進サレルモ ノモアルガ、椿ノ花粉ノ花粉管伸長八濃度 $\mathrm{M} / 50, \mathrm{M} / 100$ ナル場合八阻害サレ。 $\mathrm{M} / 300=$ 於テハ殆ド阻害サレズ、發芽率モ略同樣ノ關係デアル。酸素吸收量入濃 度 $\mathrm{M} / 100$ 二於テ僅カ $=15 \%$ ～阻害サレルガ $\mathrm{M} / 300$ 二於テハ $4 \%$ /阻害ガミラレ ルノミデアル。第五表及實驗記錄第九)

v) $\mathrm{KCl}$

酸素吸收量二就テハ濃度 $\mathrm{M} / 100$ 二於テ $35 \%$ ，阻害作用ガミラレルガ、發芽率 八對照 $48,6 \%$ =對シ僅カ $=10.8 \%$ ＼cjkstart現ハスノミデアル。（第五表及實驗記錄第 十)

以上ノ絬果ヨリ各種イオンニョリ瓦斯代謝並ビニ花粉管〉伸長ガ阻害サレル程度 ヨ順列トナシテ示セバ次ノ如クデアル。

酸素吸收量

$$
\begin{aligned}
& \mathrm{NO}_{3}>\mathrm{SO}_{4}>\mathrm{CH}_{3} \mathrm{COO}>\mathrm{PO}_{4}>\mathrm{Cl}>\mathrm{H}_{2} \mathrm{O} \\
& \mathrm{Li}>\mathrm{K}>\mathrm{Na}>\mathrm{Mg}>\mathrm{Ca}>\mathrm{H}_{2} \mathrm{O}
\end{aligned}
$$

炭酸放出量

$$
\begin{aligned}
& \mathrm{PO}_{4}>\mathrm{NO}_{3}>\mathrm{CH}_{3} \mathrm{COO}>\mathrm{SO}_{4}>\mathrm{Cl}>\mathrm{H}_{2} \mathrm{O} \\
& \mathrm{Li}>\mathrm{Mg} \geq \mathrm{Na}>\mathrm{H}_{2} \mathrm{O}
\end{aligned}
$$

空氣中二於ヶル花粉管ノ伸長

$$
\begin{aligned}
& \mathrm{NO}_{3}>\mathrm{SO}_{4}>\mathrm{CH}_{3} \mathrm{COO}>\mathrm{PO}_{4}>\mathrm{Cl}>\mathrm{H}_{2} \mathrm{O} \\
& \mathrm{Li}>\mathrm{Na}>\mathrm{K}>\mathrm{Mg}>\mathrm{Ca}>\mathrm{H}_{2} \mathrm{O}
\end{aligned}
$$

案素中二於ケル花粉管 $/$ 伸長

$$
\begin{aligned}
& \mathrm{CH}_{3} \mathrm{COO}>\mathrm{NO}_{3}>\mathrm{SO}_{4}>\mathrm{Cl}>\mathrm{PO}_{4}>\mathrm{H}_{2} \mathrm{O} \\
& \mathrm{Li}>\mathrm{Na}>\mathrm{Mg}>\mathrm{H}_{2} \mathrm{O}
\end{aligned}
$$


斯ノ如ク花粉管ノ伸長卜酸素吸收量ト八並行シテ阻害サレルノデアルカラ花粉管 ノ伸長二際シテ酸素吸收郎チ呼吸 $=ヨ リ$ 必要ナルエネルギーガ獲ラレテキルコトハ 疑モナキ事實デアル。之二反シ炭酸放出能卜花粉管つ伸長卜ノ間二八密接ナル相關 關係アルト考へルコトハ出來ナイ。尚コノコトハ窒素中二於ケル炭酸放出量ガ極メ テ著シク各種イオンニ阻害サレルニモ拘ラズ發芽率八空氣中二於ケル場合ヨリモ却 ツテ良好デアルコトョリモ考へラレルノデアル。

II. 山百合ノ花粉

山百合ノ花粉管つ伸長八椿ノ花粉つ場合卜比較スルト著シク弱ク一時間＝對スル 本均伸長ガ約 $10 \mu$ デアルカラ椿ノ場合ノ $50-80 \mu$ ， $\frac{1}{5}-\frac{1}{8}$ 程度デアル。發芽率 モ略 $20 \%$ (三時間後) ヨ數へルノミデアル。從ツテ諸璉ノイオンノ及ボス影響モ比 較的二弱ク $\mathrm{K}_{3} \mathrm{PO}_{4}$ ノ如キモノト踓モ、酸素吸收量二關シテハ濃度 $\mathrm{M} / 100$ 二於テ 少シモ阻害セズ炭酸放出二關シテノミ55\% ノ阻害作用习示スノミデアル。因ツテ 他ノ諸種ノイオンニ關シテハ $\mathrm{M} / 50$ 等量ノ阻害作用习實驗シタ。

第六表及ビ實驗記錄第十一乃至第十四ヨリ明ナルガ如ク、酸素吸收入 $50 \%=$ 達 スル阻害作用习受ケタルモノナク、又炭酸放出量モ僅カ二 $\mathrm{Li}$ ト $\mathrm{CH}_{3} \mathrm{COO}$ イオン ノミニヨリガ夫及 $53 \%$ 及ビ $60 \%$ 阻害サレタ二過ギナイノデアル。向、Ca イオ ン八酸素吸收並ビ =炭酸放出ノ何レ=モ促進的=作用シ、Mg イオン八炭酸放出= ノミ促進作用ア及ボシタノデアル。

次ニコレラ諸種ノイオンガ山百合ノ花粉二及ボシタル阻害作用 ノ如クデアル。

酸素吸收量

$$
\begin{aligned}
& \mathrm{CH}_{3} \mathrm{COO}>\mathrm{NO}_{3}>\mathrm{Cl}>\mathrm{SO}_{4}>\mathrm{H}_{2} \mathrm{O} \geq \mathrm{PO}_{4} \\
& \mathrm{Li}>\mathrm{Na}>\mathrm{K}>\mathrm{Sr}>\mathrm{Mg}>\mathrm{H}_{2} \mathrm{O}>\mathrm{Ca}
\end{aligned}
$$

炭酸放出量

$$
\begin{aligned}
& \mathrm{CH}_{3} \mathrm{COO}>\mathrm{Cl}>\mathrm{PO}_{4}>\mathrm{NO}_{3}>\mathrm{SO}_{4}>\mathrm{H}_{2} \mathrm{O} \\
& \mathrm{Li}>\mathrm{K}>\mathrm{Na}>\mathrm{Sr}>\mathrm{H}_{2} \mathrm{O}>\mathrm{Ca}>\mathrm{Mg}
\end{aligned}
$$

斯ル結果ナルガ故二椿ノ如ク花粉管ノ伸長速度ノ大ナルモノノ瓦斯代謝八山百合 ノ化花粉管伸長速度ノ小ナルモノノ瓦斯代謝ヨリモ。諸種ノイオンニョリ著シク 阻害作用习受ケル、郎チ花粉管伸長ノ難易卜瓦斯代謝ノ受ケル阻害作用卜入密接ナ ル關係ニアルト結論スルコトガ出來ルノデアル。

5. 山百合ノ花粉 $=$ 及ボス $\mathrm{Ca}$ ノ促進作用

R. A. BrINK ${ }^{1)}$ 八既 $=$ Sweet pea ノ花粉ガ $\mathrm{CaCl}_{2}, \mathrm{Ca}\left(\mathrm{NO}_{3}\right)_{2}$ 或入 $\mathrm{CaSO}_{4}$ 等ノ カルシウム鹽 $(0.01 \mathrm{M})$ ：ヨッテ發芽並ビ二花粉管ノ伸長ガ促進セラレルコト及ビ コノ促進的作用入 $\mathrm{NaCl}$ 等ノ鹽類ニヨニ阻害サレタルモノ 用ヨ示ス二至ラシメル、郎チ $\mathrm{Ca}$ イオンハ $\mathrm{Na}$ 或ハ $\mathrm{K}$ イオンニ拮抗シテ作用スル

1) R. A. Brink : loc. cit. 


\begin{tabular}{|c|c|c|c|c|c|c|c|}
\hline & & \multirow[b]{2}{*}{ 盬 } & \multicolumn{5}{|c|}{ 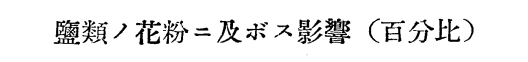 } \\
\hline & & & 0 & $\mathrm{M} / 50$ & $\mathbf{M} / 100$ & $\mathrm{M} / 200$ & $\mathrm{M} / 300$ \\
\hline \multirow{4}{*}{ 空 } & \multirow{2}{*}{$\begin{array}{c}\text { 酸 素 } \\
\text { 吸收量 } \\
\left(\mathrm{Q}_{2}\right)\end{array}$} & $\begin{array}{c}\mathrm{K}_{3} \mathrm{PO}_{4} \\
\mathrm{~K}_{2} \mathrm{SO}_{4} \\
\mathrm{KCl} \\
\mathrm{KNO}_{3} \\
\mathrm{CH}_{3} \mathrm{COOK}\end{array}$ & $\begin{array}{c}100 \\
\text { "' } \\
\text { "' } \\
\text { " }\end{array}$ & $\begin{array}{l}85 \\
93 \\
78 \\
71\end{array}$ & $\begin{array}{r}101 \\
96\end{array}$ & 100 & 106 \\
\hline & & $\begin{array}{l}\mathrm{CaCl}_{2} \\
\mathrm{MgCl}_{2} \\
\mathrm{SrCl}_{2} \\
\mathrm{KCl} \\
\mathrm{NaCl} \\
\mathrm{LiCl}\end{array}$ & $\begin{array}{l}100 \\
\text { "" } \\
\text { ". } \\
\text { " } \\
\text { " }\end{array}$ & $\begin{array}{l}81 \\
77 \\
66\end{array}$ & $\begin{array}{r}129 \\
86 \\
83\end{array}$ & & \\
\hline & \multirow{2}{*}{$\begin{array}{l}\text { 花 粉 管 } \\
\text { 伸 長 }\end{array}$} & $\begin{array}{c}\mathrm{K}_{3} \mathrm{PO}_{4} \\
\mathrm{KCl} \\
\mathrm{K}_{2} \mathrm{SO}_{4} \\
\mathrm{KNO}_{3} \\
\mathrm{CH}_{3} \mathrm{COOK}\end{array}$ & $\begin{array}{c}100 \\
\text { "1 } \\
\text { "1 } \\
\text { "1 }\end{array}$ & $\begin{array}{r}0 \\
19 \\
\\
0 \\
0\end{array}$ & $\begin{array}{r}0 \\
10\end{array}$ & 16 & 53 \\
\hline & & $\begin{array}{l}\mathrm{CaCl}_{2} \\
\mathrm{MgCl}_{2} \\
\mathrm{SrCl}_{2} \\
\mathrm{KCl} \\
\mathrm{NaCl} \\
\mathrm{LiCl}\end{array}$ & $\begin{array}{l}100 \\
\text { "I } \\
\text { "I" } \\
\text { "I } \\
\text { " }\end{array}$ & $\begin{array}{l}0 \\
0 \\
0\end{array}$ & $\begin{array}{l}0 \\
0 \\
0\end{array}$ & & \\
\hline \multirow{4}{*}{ 窒 } & \multirow{2}{*}{$\begin{array}{l}\text { 宸 酸 } \\
\text { 放出量 } \\
\left(Q_{\mathrm{CO} 2}^{\mathrm{N}_{2}}\right)\end{array}$} & $\begin{array}{c}\mathrm{K}_{3} \mathrm{SO}_{4} \\
\mathrm{KNO}_{3} \\
\mathrm{~K}_{3} \mathrm{PO}_{4} \\
\mathrm{KCl} \\
\mathrm{CH}_{3} \mathrm{COOK}\end{array}$ & $\begin{array}{c}100 \\
\text { "1 } \\
\text { "1" } \\
\text { " }\end{array}$ & $\begin{array}{l}64 \\
12 \\
50 \\
40\end{array}$ & $\begin{array}{l}69 \\
45\end{array}$ & 70 & 93 \\
\hline & & $\begin{array}{l}\mathrm{MgCl}_{2} \\
\mathrm{CaCl}_{2} \\
\mathrm{SrCl}_{2} \\
\mathrm{NaCl} \\
\mathrm{KCl} \\
\mathrm{LiCl}\end{array}$ & $\begin{array}{l}100 \\
\text { "" } \\
\text { "" } \\
\text { "" } \\
\text { " }\end{array}$ & $\begin{array}{l}75 \\
48 \\
43\end{array}$ & $\begin{array}{r}116 \\
111 \\
92\end{array}$ & & \\
\hline & \multirow{2}{*}{$\begin{array}{l}\text { 花 粉管 } \\
\text { 伸 長 }\end{array}$} & $\begin{array}{c}\mathrm{K}_{3} \mathrm{PO}_{4} \\
\mathrm{~K}_{3} \mathrm{SO}_{4} \\
\mathrm{KNO}_{3} \\
\mathrm{KCl}_{3} \\
\mathrm{CH}_{3} \mathrm{COOK}\end{array}$ & $\begin{array}{c}100 \\
\text { "1 } \\
\text { "1 } \\
\text { " }\end{array}$ & $\begin{array}{l}0 \\
\\
0 \\
0 \\
0\end{array}$ & $\begin{array}{l}0 \\
0\end{array}$ & 57 & 76 \\
\hline & & $\begin{array}{l}\mathrm{MgCl}_{2} \\
\mathrm{CaCl}_{2} \\
\mathrm{SrCl}_{2} \\
\mathrm{NaCl} \\
\mathrm{KCl} \\
\mathrm{LiCl}\end{array}$ & $\begin{array}{l}100 \\
\text { "" } \\
\text { "I } \\
\text { "" } \\
\text { "I }\end{array}$ & $\begin{array}{l}0 \\
0 \\
0\end{array}$ & $\begin{array}{l}0 \\
0 \\
0\end{array}$ & & \\
\hline
\end{tabular}

コトヨ報告シティル。同樣ノコトラ K. Gотон $^{2)}$ 氏モ報告シテキルガ P. BRAN$\operatorname{SCHEIDT}^{3)}$ 氏八酸性度 $(\mathrm{pH})$ ノ小ナル時ニ八 $\mathrm{Na}$ 並ビ $=\mathrm{K}$ イオン八 $\mathrm{Ca}$ イオン）

2) K. Gотон : loc. cit.

3) P. Branscheidt : loc. cit. 
存在二於テモ阻害的 第四圖

二作用スルガ $\mathrm{pH}$ ， やまゆり/花粉/瓦斯代謝二及ボス

大ナルトキ八促進的 作用ヨ表入スコト 實證シテキル。故二 山百合ノ場合 $=モ \mathrm{Ca}$ イオン =ョリ僅カ = 瓦斯代謝ガ促進サレ タコトラ最適濃度二 於テ確認セントシテ 實驗フ重ネタノデア 几。

第四圖並ビ = 實驗 記錄第十五 タ如ク $\mathrm{Ca}$ イオンノ 促進作用八花粉伸長 二關シテハ R. A. BRINK 氏等が報告 セルガ如ク藷シキモ 瓦斯代謝 $=$ 就テ八僅 カ二酸素吸收二於テ 18.6\% 炭酸放出二於 テ22.3\% 习促進セシ メタルニ過ギナイノ デアルガ、曲線ノ性 質ヨリ推論スレバコ ノ促進作用入時間, 增加卜共二增加スル コトハ確實ナノデア ル。實驗ノ初メ二於 テ瓦斯代謝分僅カ $=$ 阻害サレ 2 時間一 3

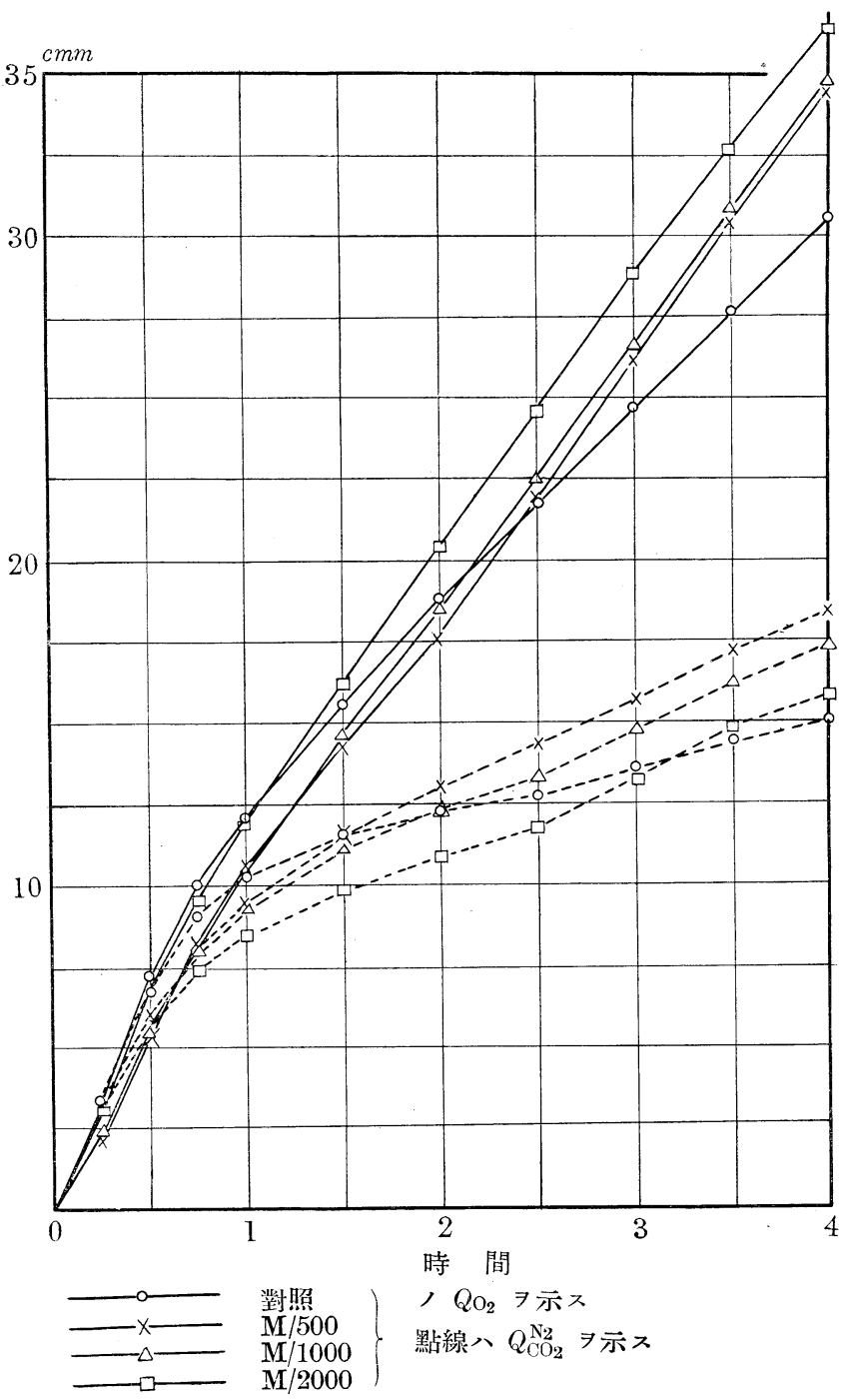

時間後二於テ促進作用ガ現ハレテ來ルコトヨリ見レバ、Ca イオン八花粉つ發芽二 作用スルヨリ八發芽七ル花粉二作用シテ花粉管〉伸長 $尹$ 促進スルコトニ大ナル意味 アリト考ヘルコトガ出來ル。

結論 花粉八葯 ニアル場合ニ八完全ナ Latentes Leben ニアルモノデメナク、極メテ僅 


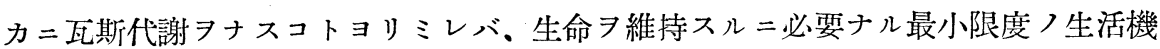
能ヨ働カシテキルモノデアツテ、發芽シ得ル狀態二置カレルト發芽センガ鹞メ＝生 活機能ヨ覺醒セシメ盛二瓦斯代謝ヨナシエネルギーヨ獲得利用スルモノデアルト考 ヘラレル。發芽二際シテハ適當ナル滲透壓ガ最モ大切デアルガ故二、糖液中二於テ 發芽七シメタル場合二八糖八適當ナル滲透壓ヨ與へルコトト後二營養物トナルコト ト二ツノ意義ヨ有スルノデアル。花粉ノ覺醒シタル生活機能=對シテハ諸種ノイオ ン八甚ダ阻害的 =作用スル。花粉管ガ伸張スル雼メ二八花粉內二眝藏サレタル物質 ガ空氣酸素ニヨツテ燃燒サレ遊離サレタルエネルギーヨ利用スルノデアルコトハ花 粉管伸張卜酸素吸收卜ノ間二並行關係ノアルコトヨリ考へラレルノデアル。又花粉 管ノ伸長速度ノ大ナルモノ八生活機能モ圓滑二進行シテキルモノデアルカラ微量ノ イオンノ滲透ニヨリ阻害サレル。之二反シテ Caイオンノ促進作用八發芽能ノ弱キ 山百合ノ花粉ニ八促進的二作用スルガ椿ノ如キ發芽能ノ强キモノニ八促進的作用 示サズ僅カ二阻害的二作用スルモノデアル、

終リ二本實驗〉逐行 ニアタリ御指導 スル。

(於德川生物學研究所)

\section{Résumé}

In vorliegender Arbeit habe ich den Gaswechsel der Pollen von Camellia japonica und Lilium auratum manometrisch (nach WARBURG) untersucht. Die erhaltenen Resultate werden folgendermassen zusammengefasst:

1. Die in den Antheren ligenden Pollen führen den Gaswechsel in sebr geringem Maße aus, aber wenn die Pollen in den keimfähigen Zustand gebracht werden, so betätigt sich der Gaswechsel sofort lebhaft.

2. Der Gaswechsel des Pollens wird bei Camellia japonica durch Zusatz des Rohrzuckers (5.0\%) unverkennbar befördert, aber keineswegs bei Lilium auratum.

3. Der Zusatz von verschiedenen Ionen wirkt auf den Gaswechsel der Pollen hemmend ein; zugleich wird die Keimung des Pollens oder Streckung des Pollenschlauches gehemmt. In Bezug auf die Stärke der Hemmung des Gaswechsels wurden die folgenden Tonenreihen festgestellt:

Bei den Pollen von Camellia japonica:

Sauerstoffaufnahme.

$$
\begin{aligned}
& \mathrm{NO}_{3}>\mathrm{SO}_{4}>\mathrm{CH}_{3} \mathrm{COO}>\mathrm{PO}_{4}>\mathrm{Cl}>\mathrm{H}_{2} \mathrm{O} \\
& \mathrm{Li}>\mathrm{K}>\mathrm{Na}>\mathrm{Mg}>\mathrm{Ca}>\mathrm{H}_{2} \mathrm{O}
\end{aligned}
$$

Kohlensäureabgabe bei der Anaerobiose.

$$
\begin{aligned}
& \mathrm{PO}_{4}>\mathrm{NO}_{3}>\mathrm{CH}_{3} \mathrm{COO}>\mathrm{SO}_{4}>\mathrm{Cl}>\mathrm{H}_{2} \mathrm{O} \\
& \mathrm{Li}>\mathrm{Mg}>\mathrm{Na}>\mathrm{H}_{2} \mathrm{O}
\end{aligned}
$$


Die Streckung des Pollenschlauches bei Aerobiose

$$
\begin{aligned}
& \mathrm{NO}_{3}>\mathrm{SO}_{4}>\mathrm{CH}_{3} \mathrm{COO}>\mathrm{PO}_{4}>\mathrm{Cl}>\mathrm{H}_{2} \mathrm{O} \\
& \mathrm{Li}>\mathrm{Na}>\mathrm{K}>\mathrm{Mg}>\mathrm{Ca}>\mathrm{H}_{2} \mathrm{O}
\end{aligned}
$$

bei Anaerobiose

$$
\begin{aligned}
& \mathrm{CH}_{3} \mathrm{COO}>\mathrm{NO}_{3}>\mathrm{SO}_{4}>\mathrm{Cl}>\mathrm{PO}_{4}>\mathrm{H}_{2} \mathrm{O} \\
& \mathrm{Li}>\mathrm{Na}>\mathrm{Mg}>\mathrm{H}_{2} \mathrm{O}
\end{aligned}
$$

Bei der Pollen von Lilium auratum: Sauerstoffaufnahme

$$
\begin{aligned}
& \mathrm{CH}_{3} \mathrm{COO}>\mathrm{NO}_{3}>\mathrm{Cl}>\mathrm{SO}_{4}>\mathrm{H}_{2} \mathrm{O} \geq \mathrm{PO}_{4} \\
& \mathrm{Li}>\mathrm{Na}>\mathrm{K}>\mathrm{Sr}>\mathrm{Mg}>\mathrm{H}_{2} \mathrm{O}>\mathrm{Ca}
\end{aligned}
$$

Kohlensäureabgabe bei der Anaerobiose

$$
\begin{aligned}
& \mathrm{CH}_{3} \mathrm{COO}>\mathrm{Cl}>\mathrm{PO}_{4}>\mathrm{NO}_{3}>\mathrm{SO}_{4}>\mathrm{H}_{2} \mathrm{O} \\
& \mathrm{Li}>\mathrm{K}>\mathrm{Na}>\mathrm{Sr}>\mathrm{H}_{2} \mathrm{O}>\mathrm{Ca}>\mathrm{Mg}
\end{aligned}
$$

\begin{tabular}{|c|c|c|c|c|c|c|c|c|}
\hline \multirow{3}{*}{$\begin{array}{lll} & \\
\text { 坌 } & \\
\text { 間 } & \\
\text { 濃度 }\end{array}$} & \multicolumn{8}{|c|}{$\mathrm{K}_{3} \mathrm{PO}_{4}$ ノつばきノ花粉二及ボス影響 } \\
\hline & \multicolumn{4}{|c|}{ 酸素吸收量 對 $1 \mathrm{mg}}$. & \multicolumn{4}{|c|}{ 崖酸放出量 對 $1 \mathrm{mg}$ (乾燥量) } \\
\hline & 0 & $\mathrm{M} / 100$ & $\mathrm{M} / 200$ & $\mathrm{M} / 300$ & 0 & $\mathrm{M} / 100$ & $\mathbf{M} / 200$ & $\mathrm{M} / 300$ \\
\hline 30 & $\begin{array}{l}\text { omm } \\
2.30\end{array}$ & $\begin{array}{l}\mathrm{cmm} \\
1.79\end{array}$ & $\begin{array}{l}\mathrm{cmm} \\
2.36\end{array}$ & $\begin{array}{l}\mathrm{cmm} \\
2.59\end{array}$ & $\begin{array}{l}\text { omm } \\
2.72\end{array}$ & $\mathrm{cmm}$ & $\mathrm{cmm}$ & $\mathrm{cmm}$ \\
\hline 60 & 5.19 & 3.63 & 5.07 & 5.99 & 3.97 & & & \\
\hline 90 & 8.01 & 4.78 & 7.20 & 8.64 & 5.33 & & & \\
\hline 120 & 11.06 & 5.76 & 8.76 & 10.49 & 6.80 & & & \\
\hline 150 & 14.52 & 6.45 & 9.62 & 11.58 & 9.75 & & & 0.79 \\
\hline 180 & & & & & 12.70 & & & 1.81 \\
\hline 210 & & & & & 16.78 & & & 3.40 \\
\hline 240 & & & & & 20.75 & & & 4.99 \\
\hline 202 & 5.81 & 2.58 & 3.85 & 4.63 & & & & \\
\hline$Q_{\mathrm{CO} 2}^{\mathrm{N}_{2}}$ & & & & & 5.19 & $\sim$ & $\sim$ & 1.25 \\
\hline 發芽紊 (\%) & 70.5 & 5.8 & 23.8 & 40.0 & 30.5 & 8.7 & 32.3 & 38.9 \\
\hline 平均伸長 $(\mu)$ & 204 & 2 & 9 & 35 & 31 & 4 & 23 & 31 \\
\hline 對 時 閒 $(\mu)$ & 81.6 & 0.8 & 3.6 & 14.0 & 8 & 1 & 5.7 & 8.0 \\
\hline
\end{tabular}

Wie aus den oben angegebenen Ionenreihen ersichtlich, steht es hierbei fest, dass ein Parallelismus zwischen der Hemmung der Sauerstoffaufnahme und der Streckung des Pollenschlanches vorhanden ist.

4. Ca-Ionen, die, wie schon BrInk mitgeteilt hat, auf die Streckung des Pollens begünstigend wirken, befördern auch den Gaswechsel des Pollens von Lilium auratum.

\section{實 驗 記 録}


第 二

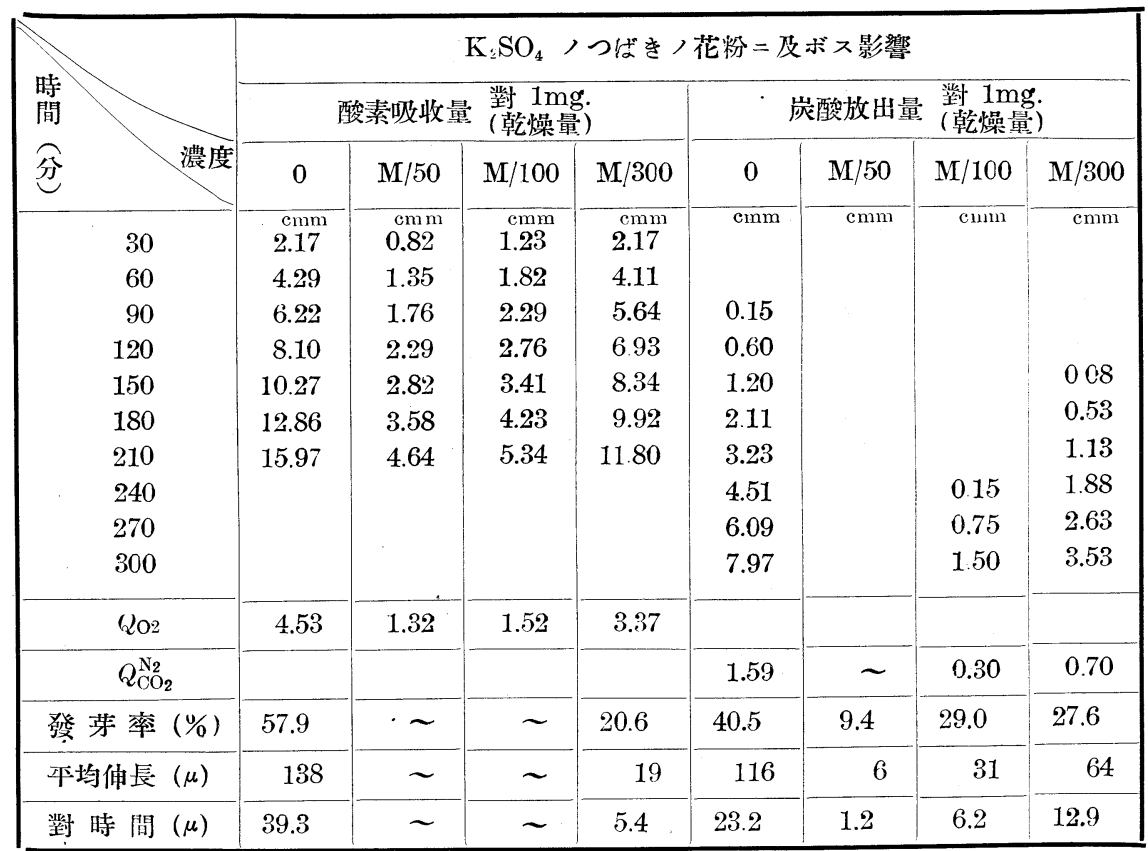

第 三

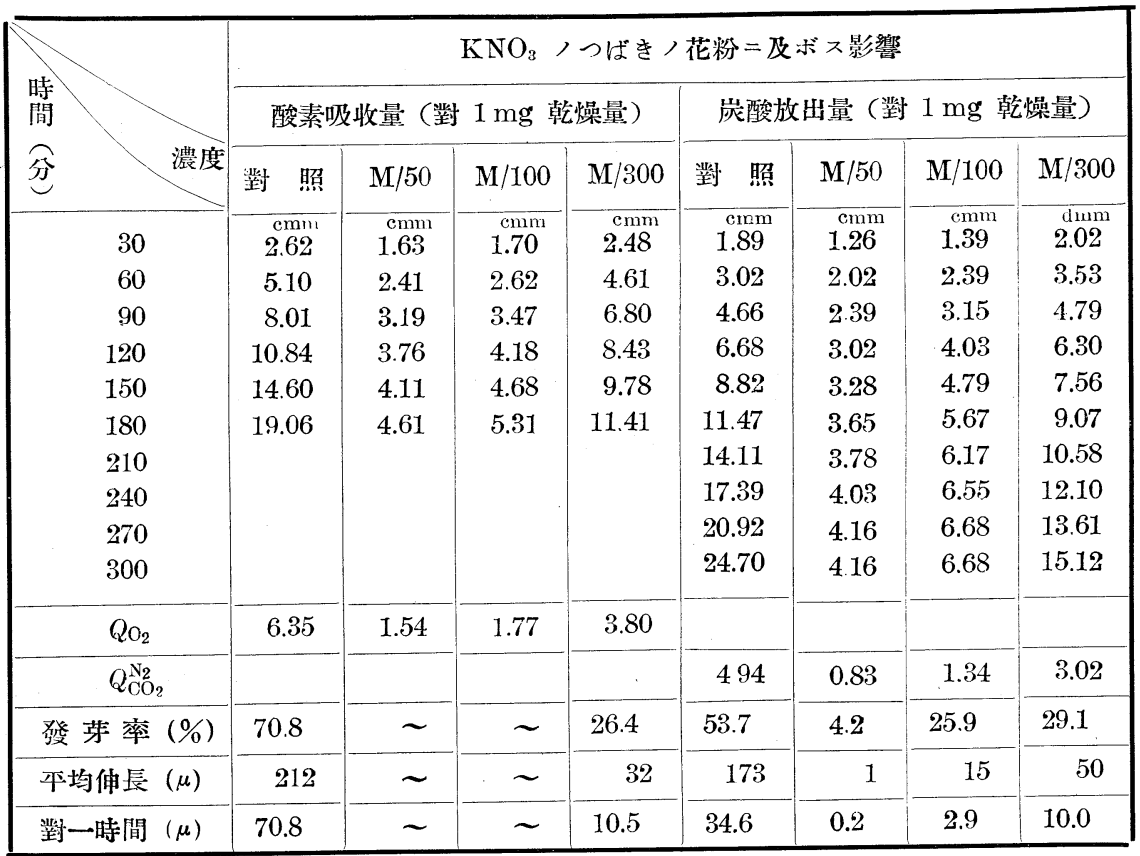


第

四

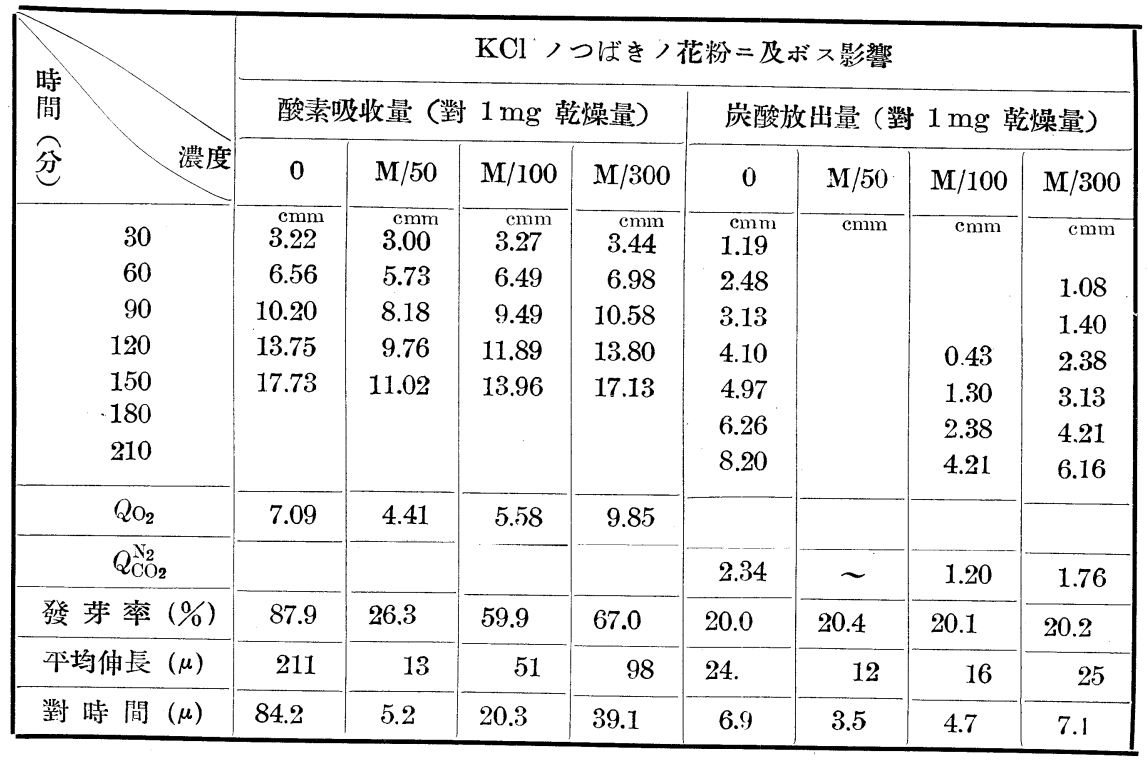

第

五

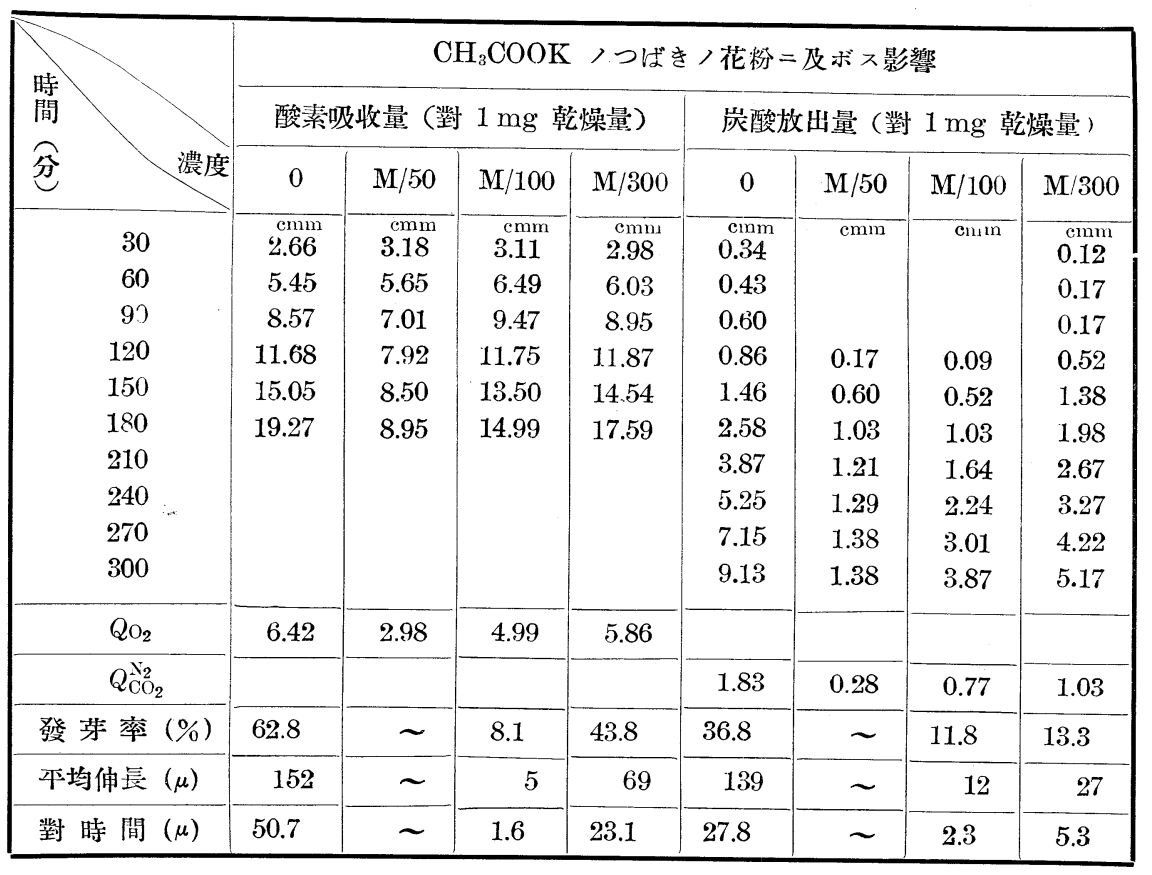


第

六

$\mathrm{NaCl}$ ノつばきノ花粉二及ボス影響

\begin{tabular}{|c|c|c|c|c|c|c|c|c|}
\hline 間 & 酸素 & 收量（梓 & $1 \mathrm{mg}$ 龺 & 橾量) & 宸酸 & 出量（当 & $1 \mathrm{mg}$ 幹 & 懆量) \\
\hline 辰 & 0 & $\mathrm{M} / 50$ & $\mathrm{M} / 100$ & $\mathrm{M} / 300$ & 0 & $\mathrm{M} / 50$ & $\mathrm{M} / 100$ & $\mathbf{M} / 300$ \\
\hline 30 & $\begin{array}{l}\text { cmut } \\
2.35\end{array}$ & $\begin{array}{l}\mathrm{cmm} \\
1.91\end{array}$ & $\begin{array}{l}\text { cinm } \\
2.13\end{array}$ & $\begin{array}{l}\mathrm{cmm} \\
2.13\end{array}$ & $\mathrm{cmm}$ & $\mathrm{cmm}$ & $\mathrm{cmm}$ & $\mathrm{cmm}$ \\
\hline 60 & 4.11 & 3.23 & 3.82 & 3.89 & & & & \\
\hline 90 & 5.65 & 4.11 & 4.99 & 5.43 & & & & \\
\hline 120 & 7.41 & 4.99 & 6.17 & 6.97 & & & & \\
\hline 150 & 9.32 & 5.80 & 7.19 & 8.59 & & & & \\
\hline 180 & 11.16 & 6.31 & 8.07 & 10.20 & 0.57 & & 0.19 & 0.38 \\
\hline 210 & & & & & 1.32 & & 0.44 & 0.88 \\
\hline 240 & & & & & 2.21 & & 0.63 & 1.39 \\
\hline 270 & & & & & 3.47 & & 1.01 & 1.95 \\
\hline 300 & & & & & 5.61 & 0.69 & 1.64 & 3.21 \\
\hline 330 & & & & & 6.68 & 1.26 & 2.71 & 4.54 \\
\hline 360 & & & & & 9.07 & 1.26 & 3.91 & 5.10 \\
\hline$Q_{\mathrm{O}_{2}}$ & 3.72 & 2.10 & 2.69 & 3.40 & & & & \\
\hline$Q_{\mathrm{CO}_{2}}^{\mathrm{N}_{2}}$ & & & & & 1.51 & 0.21 & 0.65 & 0.85 \\
\hline 發芽紊 $(\%)$ & 5.27 & 2.3 & 10.2 & 43.6 & 42.7 & 29.4 & 36.8 & 36.4 \\
\hline 平均伸長 $(\mu)$ & 132 & 1 & 10 & 72 & 144 & 24 & 48 & 70 \\
\hline 對 時間 $(\mu)$ & 44.1 & 0.3 & 3.4 & 23.9 & 24.1 & 4.0 & 8.0 & 117 \\
\hline
\end{tabular}

第 七

\begin{tabular}{|c|c|c|c|c|c|c|c|c|}
\hline \multirow{3}{*}{ 分 濃度 } & \multicolumn{8}{|c|}{$\mathrm{MgCl}_{2}$ ノつばきノ花粉二及ボス影響 } \\
\hline & \multicolumn{4}{|c|}{ 酸素吸收量 (對 $1 \mathrm{mg}$ 乾燥量) } & \multicolumn{4}{|c|}{ 崖酸放出量 (對 $1 \mathrm{mg}$ 䫧燥量) } \\
\hline & 0 & $\mathrm{M} / 50$ & $\mathrm{M} / 100$ & $\mathrm{M} / 300$ & 0 & $\mathrm{M} / 500$ & $\mathrm{M} / 100$ & $\mathrm{M} / 300$ \\
\hline 30 & $\begin{array}{c}\operatorname{cnmm} \\
1.97\end{array}$ & $\mathrm{cmm}$ & 1.65 & $\begin{array}{l}\mathrm{cmm} \\
2.03\end{array}$ & $\mathrm{cmm}$ & $\mathrm{cmm}$ & emm & $\mathrm{cmm}$ \\
\hline 60 & 3.75 & 2.73 & 2.80 & 3.62 & & & & \\
\hline 90 & 5.47 & 3.75 & 3.88 & 5.08 & & & & \\
\hline 120 & 7.24 & 4.70 & 483 & 6.42 & & & & \\
\hline 150 & 9.41 & 5.78 & 6.04 & 7.94 & & & & \\
\hline 180 & 11.57 & 6.74 & 7.05 & 9.47 & & & & \\
\hline 210 & & & & & 0.15 & & & \\
\hline 240 & & & & & 0.44 & & 0.29 & 0.07 \\
\hline 270 & & & & & 0.73 & & 0.44 & 0.15 \\
\hline 300 & & & & & 1.31 & & 0.58 & 0.29 \\
\hline 330 & & & & & 2.03 & & 0.80 & 0.58 \\
\hline 360 & & & & & 2.97 & & 0.94 & 0.80 \\
\hline $\mathrm{QO}_{2}$ & 3.86 & 2.25 & 2.35 & 3.16 & & & & \\
\hline$Q_{\mathrm{CO}_{2}}^{\mathrm{N}_{2}}$ & & & & & 0.49 & $\sim$ & 0.15 & 0.13 \\
\hline 發芽率 (\%) & 44.5 & 10.8 & 16.8 & 39.5 & 39.5 & 13.5 & 23.2 & 27.8 \\
\hline 平均伸長 $(\mu)$ & 119 & 7 & 25 & 72 & 107 & 11 & 30 & 36 \\
\hline 對 時 間 $(\mu)$ & 39.6 & 2.4 & 8.4 & 24.1 & 17.8 & 1.8 & 5.0 & 5.9 \\
\hline
\end{tabular}




\begin{tabular}{|c|c|c|c|c|c|c|c|c|}
\hline \multirow{3}{*}{$\begin{array}{l}\text { 時 } \\
\text { 間 } \\
\text { 分 }\end{array}$} & \multicolumn{8}{|c|}{$\mathrm{LiCl}$ ノつばきノ花粉二及ボス影帞 } \\
\hline & \multicolumn{4}{|c|}{ 酸素吸收量 (對 $1 \mathrm{mg}$ 乾燥量) } & \multicolumn{4}{|c|}{ 炭酸放出量（對 $1 \mathrm{mg}$ 乾燥量） } \\
\hline & 0 & $\mathrm{M} / 50$ & $\mathrm{M} / 100$ & $\mathrm{M} / 300$ & 0 & $\mathrm{M} / 50$ & $\mathrm{M} / \mathrm{I} 00$ & $\mathbf{M} / 30$ \\
\hline 30 & $\begin{array}{l}\mathrm{cmm} \\
2.04\end{array}$ & $\begin{array}{c}\mathrm{cmm} \\
132\end{array}$ & $\begin{array}{c}\mathrm{cmm} \\
1.53\end{array}$ & $\begin{array}{c}\operatorname{cinm} \\
1.73\end{array}$ & $\mathrm{cmm}$ & $\overline{\mathrm{cmm}}$ & $\mathrm{cmm}$ & $\mathrm{cmm}$ \\
\hline 60 & 3.97 & 2.34 & 2.55 & 3.06 & & & & \\
\hline 90 & 6.01 & 3.36 & 3.57 & 4.59 & 0.12 & & & \\
\hline 120 & 8.36 & 4.28 & 4.69 & 6.11 & 0.41 & & & 0.06 \\
\hline 150 & 11.00 & 5.20 & 5.60 & 7.34 & 1.06 & & & 0.24 \\
\hline 180 & 14.06 & 5.91 & 6.22 & 8.36 & 1.71 & & & 0.35 \\
\hline 210 & 17.42 & 6.52 & 6.83 & 9.17 & 2.47 & & & 0.47 \\
\hline 240 & & & & & 3.29 & & & 0.76 \\
\hline 270 & & & & & 4.12 & & & 1.00 \\
\hline 300 & & & & & 4.94 & & & 1.23 \\
\hline$Q_{\mathrm{O}_{2}}$ & 4.97 & 1.86 & 1.95 & 2.62 & & & & \\
\hline$Q_{\mathrm{CO} 2}^{\mathrm{N}_{2}}$ & & & & & 0.99 & $\sim$ & $\sim$ & 0.25 \\
\hline 發 牙 率 $(\%)$ & 57.9 & $\sim$ & $\sim$ & 4.7 & 32.9 & $\sim$ & 4.7 & 9.3 \\
\hline 平均伸長 $(\mu)$ & 196 & $\sim$ & $\sim$ & 1 & 75 & $\sim$ & 1 & 2 \\
\hline 對 時 間 $(\mu)$ & 56.1 & $\sim$ & $\sim$ & 0.4 & 15 & $\sim$ & 0.1 & 0.4 \\
\hline
\end{tabular}

第

九

\begin{tabular}{|c|c|c|c|c|}
\hline & \multicolumn{4}{|c|}{$\mathrm{CaCl}_{2}$ ノつばきノ花枌二及ボス影響 } \\
\hline 間 & \multicolumn{4}{|c|}{ 酸素吸收量 (對 $1 \mathrm{mg}$ 軲燥量) } \\
\hline 濃度 & 0 & $\mathrm{M} / 50$ & $\mathrm{M} / 100$ & $\mathrm{M} / 300$ \\
\hline 30 & $\begin{array}{c}\text { cmm } \\
2.20\end{array}$ & $\begin{array}{l}\operatorname{cmm} \\
1.76\end{array}$ & $\begin{array}{l}\text { cmm } \\
2.08\end{array}$ & $\begin{array}{l}\mathrm{cmm} \\
2.14\end{array}$ \\
\hline 60 & 4.34 & 3.46 & 4.09 & 4.28 \\
\hline 90 & 6.00 & 5.47 & 6.04 & 6.42 \\
\hline 120 & 9.25 & 7.61 & 8.30 & 9.06 \\
\hline 150 & 12.52 & 9.94 & 10.82 & 12.01 \\
\hline 180 & 15.79 & 12.27 & 13.46 & 15.22 \\
\hline$Q_{\mathrm{O}_{2}}$ & 5.25 & 4.09 & 4.49 & 5.07 \\
\hline 發芽率（\%) & 66.8 & 25.8 & 54.8 & 60.9 \\
\hline 平均伸長 $(\mu)$ & 225 & 14 & 108 & 221 \\
\hline 對 時 間 $(\mu)$ & 75.0 & 4.7 & 35.9 & 73.6 \\
\hline
\end{tabular}


第 $\quad+$

\begin{tabular}{|c|c|c|c|c|}
\hline & \multicolumn{4}{|c|}{$\mathrm{KCl}$ ノつばきノ花粉=及ボス影響 } \\
\hline & \multicolumn{4}{|c|}{ 酸素吸收量（對 $1 \mathrm{mg}$ 乾燥量） } \\
\hline & 0 & $\mathrm{M} / 50$ & $\mathrm{M} / 100$ & $\mathrm{M} / 300$ \\
\hline 30 & 1.84 & 1.51 & $\begin{array}{l}\mathrm{cmm} \\
1.51\end{array}$ & $\begin{array}{l}\mathrm{cmm} \\
1.51\end{array}$ \\
\hline 60 & 3.57 & 2.49 & 2.49 & 3.03 \\
\hline 90 & 5.08 & 3.46 & 3.89 & 4.54 \\
\hline 120 & 6.81 & 4.43 & 4.87 & 5.95 \\
\hline 150 & 8.65 & 5.08 & 5.84 & 7.46 \\
\hline 180 & 10.71 & 5.95 & 6.92 & 8.98 \\
\hline $\mathrm{QO}_{2}$ & 3.57 & 1.98 & 2.31 & 2.00 \\
\hline 發芽率（\%) & 48.6 & 2.0 & 10.8 & 29.1 \\
\hline 平均伸長 $(\mu)$ & 140 & 1 & 12 & 79 \\
\hline 對 時 間 $(\mu)$ & 46.6 & 0.3 & 4.1 & 26.5 \\
\hline
\end{tabular}

第 十 -

\begin{tabular}{|c|c|c|c|c|c|c|c|c|c|c|}
\hline \multirow{3}{*}{$\begin{array}{l}\text { 時 } \\
\text { 間 } \\
\text { 分 }\end{array}$} & \multicolumn{10}{|c|}{$\mathrm{K}_{3} \mathrm{PO}_{4}$ ノやまゆりノ花粉二及ボス影響 } \\
\hline & \multicolumn{5}{|c|}{ 酸素吸收量 (對 $1 \mathrm{mg}$ 乾燥量) } & \multicolumn{5}{|c|}{ 崖酸放出量 (對 $1 \mathrm{mg}$ 乾燥量) } \\
\hline & 0 & $\mathrm{M} / 50$ & $\mathrm{M} / 100$ & $\mathrm{M} / 200$ & $\mathrm{M} / 300$ & 0 & $\mathrm{M} / 50$ & $\mathrm{M} / 100$ & $\mathrm{M} / 200$ & $\mathrm{M} / 300$ \\
\hline 30 & $\begin{array}{l}\mathrm{cmm} \\
7.63\end{array}$ & $\begin{array}{l}\mathrm{cmm} \\
512\end{array}$ & $\begin{array}{l}\mathrm{cmm} \\
5.64\end{array}$ & $\begin{array}{l}\mathrm{cmm} \\
6.25\end{array}$ & $\begin{array}{c}\mathrm{cmm} \\
5.47\end{array}$ & $\begin{array}{l}\operatorname{cmm} \\
7.79\end{array}$ & $\begin{array}{l}\mathrm{cmm} \\
1.12\end{array}$ & $\begin{array}{l}\mathrm{cmm} \\
2.77\end{array}$ & $\begin{array}{l}\operatorname{cmm} \\
5.54\end{array}$ & $\begin{array}{l}\mathrm{cmm} \\
6.07\end{array}$ \\
\hline 60 & 10.67 & 8.07 & 8.94 & 9.46 & 9.02 & 12.21 & 1.65 & 4.42 & 8.32 & 10.30 \\
\hline 90 & 12.67 & 10.34 & 11.28 & 11.54 & 11.45 & 13.33 & 1.72 & 5.54 & 9.24 & 12.14 \\
\hline 120 & 14.57 & 12.15 & 13.79 & 13.88 & 14.14 & 13.86 & 1.72 & 6.14 & 9.50 & 12.94 \\
\hline 150 & 15.62 & 13.10 & 15.44 & 15.35 & 16.05 & 14.78 & 1.72 & 6.67 & 10.32 & 13.73 \\
\hline 180 & 16.48 & 13.97 & 16.66 & 16.48 & 17.44 & & & & & \\
\hline $\mathrm{QO}_{2}$ & 5.49 & 4.66 & 5.55 & 5.49 & 5.81 & & & & & \\
\hline$Q_{\mathrm{CO}_{2}}^{\mathrm{N}_{2}}$ & & & & & & 5.91 & 0.68 & 2.66 & 4.12 & 5.49 \\
\hline 發芽率（\%) & 23.4 & $\sim$ & - & 12.1 & 24.5 & 9.5 & $\sim$ & $\sim$ & 7.8 & 11.1 \\
\hline 平均伸長 $(\mu)$ & 32 & $\sim$ & $\sim$ & 5 & 17 & 21 & $\sim$ & $\sim$ & 12 & 16 \\
\hline 對 時 間 $(\mu)$ & 10.6 & $\sim$ & $\sim$ & 1.7 & 5.6 & 8.4 & $\sim$ & $\sim$ & 4.8 & 6.4 \\
\hline
\end{tabular}


第 十二

\begin{tabular}{|c|c|c|c|c|c|c|c|c|c|c|}
\hline \multirow{3}{*}{ 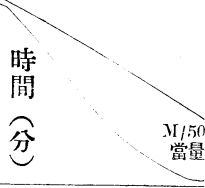 } & \multicolumn{10}{|c|}{$\mathrm{KCl}, \mathrm{KNO}_{3}, \mathrm{~K}_{2} \mathrm{SO}, \mathrm{CH}_{3} \mathrm{COOK}$ 八やまゆり/花粉二及ボス影響 } \\
\hline & \multicolumn{5}{|c|}{ 酸素吸收量 (對 $1 \mathrm{mg}$ 乾燥量) } & \multicolumn{5}{|c|}{ 孷酸放出量 (對 $1 \mathrm{mg}$ 乾燥量) } \\
\hline & 對照 & $\mathrm{KCl}$ & $\mathrm{KNO}_{3}$ & $\mathrm{~K}_{2} \mathrm{SO}_{4}$ & $\mathrm{CH}_{3}$ & 對照 & $\mathrm{KCl}$ & $\mathrm{KNO}_{3}$ & $\mathrm{~K}_{2} \mathrm{SO}_{4}$ & ${ }_{\mathrm{COOK}}^{\mathrm{CH}_{3}}$ \\
\hline 15 & $\begin{array}{l}\mathrm{cmm} \\
2.82\end{array}$ & $\begin{array}{l}\mathrm{cn} \\
2 .\end{array}$ & & $\begin{array}{l}\mathrm{cmm} \\
3.04\end{array}$ & $\frac{\operatorname{cmm}}{2.43}$ & $\begin{array}{l}\mathrm{cmm} \\
3.12\end{array}$ & $\mathrm{cml}$ & $\begin{array}{l}\mathrm{cmm} \\
2.39\end{array}$ & $\frac{5 \mathrm{~mm}}{3.25}$ & $\operatorname{cosm}_{1.78}$ \\
\hline 30 & 5.56 & 5.29 & 3. & 5.64 & 4.19 & $5.7 C$ & 4.23 & 3.74 & 78 & 2. \\
\hline 45 & 8.86 & 7.98 & 5. & 8.4 & 6.17 & 7.2 & 4 & 4.29 & & \\
\hline 60 & 11.69 & 10.54 & 7.23 & 11.16 & 8.25 & 8. & 4. & 4.78 & & \\
\hline 9 & 15.61 & 14.46 & 10.28 & 15.00 & 11.11 & 8.88 & 4. & 5.2 & & \\
\hline 120 & 19.80 & 18.48 & 14.77 & \begin{tabular}{|l|l} 
& 19.23
\end{tabular} & 14.11 & 9.07 & 4. & 5.5 & 6.0 & \\
\hline 150 & 23.46 & 21.96 & 18.07 & 22.83 & 16.63 & 9.43 & 4. & 5.94 & 6.37 & \\
\hline 180 & 26.81 & 24.89 & 21.02 & 25.87 & 18.94 & 9.86 & 4.90 & 6.31 & 6.68 & 3.9 \\
\hline $\mathrm{QO}_{2}$ & 8.94 & 8.29 & 7.01 & 0.02 & 6.31 & & & & & \\
\hline$Q_{\mathrm{CO}_{2}}^{\mathrm{N}_{2}}$ & & & & & & 3.29 & 1.63 & 2.10 & 2.28 & $1.3 \mathrm{~s}$ \\
\hline 發芽率（\%) & 15.0 & 5.0 & $\sim$ & 3.4 & $\sim$ & 4.4 & $\sim$ & $\sim$ & - & $\sim$ \\
\hline 平均伸長 $(\mu)$ & 15 & 2 & 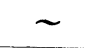 & 1 & $\sim$ & 2 & $\sim$ & $\sim$ & $\sim$ & $\sim$ \\
\hline 對時 間 $(\mu)$ & 3.8 & 0.6 & $\sim$ & 0.4 & $\sim$ & 0.6 & $\sim$ & $\sim$ & $\sim$ & $\sim$ \\
\hline
\end{tabular}

第 + 三

\begin{tabular}{|c|c|c|c|c|c|c|c|c|c|c|}
\hline \multirow{3}{*}{ 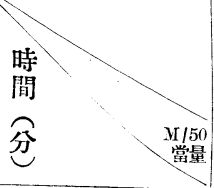 } & \multicolumn{10}{|c|}{$\mathrm{KCl}, \mathrm{NaCl}, \mathrm{CaCl}_{2}, \mathrm{LiCl}$ ノやまゆりノ花粉二及ボス影響 } \\
\hline & \multicolumn{5}{|c|}{ 酸素吸收量（對 $1 \mathrm{mg}$ 乾燥量） } & \multicolumn{5}{|c|}{ 炭酸放出量（對 $1 \mathrm{mg}$ 乾燥量） } \\
\hline & 對照 & $\mathrm{KCl}$ & $\mathrm{NaCl}$ & $\mathrm{CaCl}_{2}$ & $\mathrm{LiCl}$ & 對照 & $\mathrm{KCl}$ & $\mathrm{NaCl}$ & $\mathrm{CaCl}_{2}$ & $\mathrm{LiCl}$ \\
\hline 15 & $\begin{array}{l}\lim _{2} \\
2.86\end{array}$ & $\begin{array}{ll}c \operatorname{com} \\
2.51\end{array}$ & $\begin{array}{l}\mathrm{cmm} \\
3.09\end{array}$ & $\begin{array}{l}\mathrm{cmm} \\
2.27\end{array}$ & $\begin{array}{l}\operatorname{comm} \\
2.62\end{array}$ & $\operatorname{cimm}$ & $\mathrm{cmm}$ & cnim & $\overline{\mathrm{cmm}}$ & $\mathrm{cmm}$ \\
\hline 30 & 6.24 & 5.19 & 5.66 & 5.19 & 5.01 & 6.24 & 4.83 & 4.33 & 4.99 & 4.24 \\
\hline 45 & 8.63 & 6.88 & 7.23 & 7.93 & 6.35 & 7.49 & 5.08 & 5.16 & 6.16 & 4.49 \\
\hline 60 & 10.32 & 8.16 & 8.45 & 10.44 & 7.35 & 7.99 & 5.08 & 5.49 & 6.74 & 4.49 \\
\hline 90 & 13.06 & 10.38 & 10.55 & 14.75 & 9.21 & 8.99 & 5.08 & 6.16 & 8.15 & 4.49 \\
\hline 120 & 15.33 & 1230 & 12.18 & 18.19 & 10.61 & 9.57 & 5.08 & 6.74 & 9.32 & 4.49 \\
\hline 150 & 17.49 & 14.17 & 13.70 & 21.86 & 11.78 & 9.90 & 5.08 & 7.07 & 10.32 & 4.49 \\
\hline 180 & 19.71 & 15.97 & 15.22 & 25.48 & 13.00 & 10.48 & 5.08 & 7.90 & 11.65 & 4.49 \\
\hline$Q_{\mathrm{O}_{2}}$ & 6.57 & 5.32 & 5.07 & 8.49 & 4.33 & & & & & \\
\hline$Q_{\mathrm{CO}_{2}}^{\mathrm{N}_{2}}$ & & & & & & & 1.69 & 2.63 & 3.88 & 1.49 \\
\hline 發芽率 (\%) & 18.9 & $\sim$ & $\sim$ & 46.7 & $\sim$ & 3.49 & $\sim$ & $\sim$ & $\sim$ & $\sim$ \\
\hline 平均伸長 $(\mu)$ & 21 & $\sim$ & $\sim$ & 50 & $\sim$ & 3 & $\sim$ & $\sim$ & $\sim$ & $\sim$ \\
\hline 對時 間 $(\mu)$ & 6.9 & $\sim$ & $\sim$ & 169 & $\sim$ & 1.0 & $\sim$ & $\sim$ & $\sim$ & $\sim$ \\
\hline
\end{tabular}


第 十灯

\begin{tabular}{|c|c|c|c|c|c|c|}
\hline$>$ & \multicolumn{6}{|c|}{$\mathrm{MgCl}_{2}, \mathrm{~S} \mathrm{Cl}_{2}$ ノやまゆりノ花汾二及ボス影響 } \\
\hline 簡 & 酸素吸收 & 曼(對 $1 \mathrm{n}$ & 乾燥量 & 㞸酸放击 & (對 $1 r$ & 乾燥量) \\
\hline 分 & 對 照 & $\mathrm{MgCl}_{2}$ & $\mathrm{SrCl}_{2}$ & 對 照 & $\mathrm{SrCl}_{2}$ & $\mathrm{MgCl}_{2}$ \\
\hline 15 & 3.07 & $\begin{array}{ll}\mathrm{c} \operatorname{cnm} \\
3.00\end{array}$ & 1.75 & 1.81 & $\begin{array}{l}\mathrm{cmm} \\
0.73\end{array}$ & $\begin{array}{l}\mathrm{cmm} \\
1.13\end{array}$ \\
\hline 30 & 5.33 & 4.97 & 3.80 & 2.65 & 1.26 & 1.90 \\
\hline 45 & 7.45 & 6.65 & 5.11 & 3.17 & 1.66 & 2.49 \\
\hline 60 & 10.08 & 8.55 & 7.08 & 3.56 & 2.06 & 3.02 \\
\hline 90 & 13.88 & 11.69 & 10.52 & 4.17 & 2.83 & 4.10 \\
\hline 120 & 17.45 & 14.68 & 13.81 & 4.81 & 3.68 & 5.12 \\
\hline 150 & 20.89 & 17.68 & 16.80 & 5.52 & 4.76 & 6.20 \\
\hline 180 & 23.96 & 20.60 & 20.01 & 6.07 & 5.59 & 7.03 \\
\hline $\mathrm{QO}_{2}$ & 7.99 & 68.7 & 6.67 & & & \\
\hline$Q_{\mathrm{CO}_{2}}^{\mathrm{N}_{2}}$ & & & & 2.02 & 1.86 & 2.34 \\
\hline
\end{tabular}

第十五

\begin{tabular}{|c|c|c|c|c|c|c|c|c|}
\hline \multirow{3}{*}{$\begin{array}{l}\text { 時 } \\
\text { 間 } \\
\text { 贫 }\end{array}$} & \multicolumn{8}{|c|}{$\mathrm{CaCl}_{2}$ やや委ゆり，花岎二及ボス代謝促進作用 } \\
\hline & \multicolumn{4}{|c|}{ 酸素吸收量 (對 $1 \mathrm{mg}$ 乾燥量) } & \multicolumn{4}{|c|}{ 炭酸放出量 (對 $1 \mathrm{mg}$ 乾燥量) } \\
\hline & 0 & $\mathrm{M} / 500$ & $\mathrm{M} / 1000$ & $\mathbf{M} / 2000$ & 0 & $\mathrm{M} / 500$ & $\mathbf{M} / 1000$ & $\mathrm{M} / 2000$ \\
\hline 15 & $\begin{array}{l}\text { cmmin } \\
3.33\end{array}$ & $\begin{array}{l}\mathrm{cmm} \\
2.11\end{array}$ & $\begin{array}{l}\mathrm{cmm} \\
2.29\end{array}$ & $\stackrel{\mathrm{cmm}}{3.14}$ & $\begin{array}{l}\mathrm{cmm} \\
3.37\end{array}$ & $\begin{array}{l}\text { cmm } \\
3.37\end{array}$ & $\begin{array}{l}\mathrm{cmm} \\
3.27\end{array}$ & $\begin{array}{l}\text { cmm } \\
3.12\end{array}$ \\
\hline 30 & 7.21 & 5.33 & 5.52 & 6.65 & 6.70 & 598 & 5.88 & 5.62 \\
\hline 45 & 9.98 & 8.06 & 8.20 & 9.47 & 9.09 & 7.91 & 7.80 & 7.34 \\
\hline 60 & 12.04 & 10.54 & 10.40 & 11.81 & 10.28 & 9.40 & 9.20 & 8.38 \\
\hline 90 & 15.63 & 14.26 & 14.50 & 16.24 & 11.58 & 1148 & 11.07 & 9.83 \\
\hline 120 & 18.86 & 17.65 & 18.48 & 20.41 & 12.28 & 12.99 & 12.33 & 10.89 \\
\hline 150 & 21.79 & 21.98 & 22.49 & 24.52 & 12.76 & 14.30 & 13.37 & 11.78 \\
\hline 180 & 24.75 & 26.15 & 26.68 & 28.60 & 13.60 & 15.70 & 14.78 & 13.29 \\
\hline 210 & 27.74 & 30.50 & 30.89 & 32.67 & 1448 & 17.20 & 16.22 & 14.79 \\
\hline 240 & 30.65 & 34.55 & 34.74 & 36.39 & 15.06 & 18.45 & 17.42 & 1588 \\
\hline$Q_{O_{2}}$ & 5.11 & 5.76 & 579 & 6.06 & & & & \\
\hline$Q_{\mathrm{CO}}^{\mathrm{N}_{2}}$ & & & & & 2.51 & 3.07 & 290 & 2.65 \\
\hline 發芽率（\%) & 24.1 & 42.0 & 35.0 & 37.2 & 10.9 & 26.5 & 30.2 & 31.4 \\
\hline 平均伸長 $(\mu)$ & 44 & 133 & 139 & 124 & 20 & 31 & 36 & 47 \\
\hline 對時閒 $(\mu)$ & 10.9 & 33.3 & 34.7 & 30.9 & 5.0 & 78 & 8.9 & 11.7 \\
\hline
\end{tabular}

